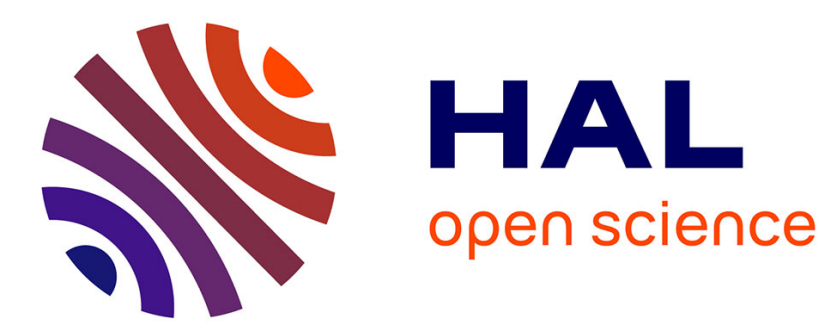

\title{
Novel free-radical mediated lipid peroxidation biomarkers in newborn plasma
}

\author{
Ángel Sánchez-Illana, Sudhin Thayyil, Paolo Montaldo, Dorothea Jenkins, \\ Guillermo Quintas, Camille Oger, Jean-Marie Galano, Claire Vigor, Thierry \\ Durand, Máximo Vento, et al.
}

\section{To cite this version:}

Ángel Sánchez-Illana, Sudhin Thayyil, Paolo Montaldo, Dorothea Jenkins, Guillermo Quintas, et al.. Novel free-radical mediated lipid peroxidation biomarkers in newborn plasma. Analytica Chimica Acta, 2017, 996, pp.88-97. 10.1016/j.aca.2017.09.026 . hal-02594586

\section{HAL Id: hal-02594586 https://hal.science/hal-02594586}

Submitted on 15 May 2020

HAL is a multi-disciplinary open access archive for the deposit and dissemination of scientific research documents, whether they are published or not. The documents may come from teaching and research institutions in France or abroad, or from public or private research centers.
L'archive ouverte pluridisciplinaire HAL, est destinée au dépôt et à la diffusion de documents scientifiques de niveau recherche, publiés ou non, émanant des établissements d'enseignement et de recherche français ou étrangers, des laboratoires publics ou privés. 


\title{
Novel free-radical mediated lipid peroxidation biomarkers in newborn plasma
}

\author{
Ángel Sánchez-Illana a , Sudhin Thayyil ${ }^{\mathrm{b}}$, Paolo Montaldo ${ }^{\mathrm{b}}$, Dorothea Jenkins ${ }^{\mathrm{c}}$, \\ Guillermo Quintás ${ }^{\mathrm{d}, \mathrm{e}}$, Camille Oger ${ }^{\mathrm{f}}$, Jean-Marie Galano ${ }^{\mathrm{f}}$, Claire Vigor ${ }^{\mathrm{f}}$, Thierry Durand ${ }^{\mathrm{f}}$, \\ Máximo Vento ${ }^{\mathrm{a}, \mathrm{g}}$, Julia Kuligowski ${ }^{\text {a, }}$ " \\ ${ }^{a}$ Neonatal Research Group, Health Research Institute Hospital La Fe, Avenida Fernando Abril Martorell 106, 46026 Valencia, Spain \\ ${ }^{\mathrm{b}}$ Centre for Perinatal Neuroscience, Imperial College London, UK \\ ${ }^{c}$ Department of Pediatrics, Medical University of South Carolina, USA \\ d Bioanalysis and Metabolomcs, Leitat Technological Center, Avenida Fernando Abril Martorell 106, 46026 Valencia, Spain \\ e Unidad Analítica, Health Research Institute La Fe, Avenida Fernando Abril Martorell 106, 46026 Valencia, Spain \\ ${ }_{\mathrm{f}}^{\mathrm{f}}$ Institut des Biomolécules Max Mousseron, UMR 5247 CNRS, ENSCM, Université de Montpellier, Montpellier, France \\ ${ }^{g}$ Division of Neonatology, University \& Polytechnic Hospital La Fe, Avenida Fernando Abril Martorell 106, Valencia, Spain
}

Oxidative stress derived from perinatal asphyxia appears to be closely linked to neonatal brain damage and lipid peroxidation biomarkers have shown to provide predictive power of oxidative stress related pathologies in situations of hypoxia and reoxygenation in the newborn. The objective of this work was to develop and validate of a comprehensive liquid chromatography tandem mass spectrometry approach for the quantitative profiling of 28 isoprostanoids in newborn plasma samples covering a broad range of lipid peroxidation product classes. The method was developed taking into account the specific requirements for its use in neonatology (i.e. limited sample volumes, straightforward sample processing and high analytical throughput). The method was validated following stringent FDA guidelines and was then applied to the analysis of 150 plasma samples collected from newborns. Information obtained from

Abbreviations: $\mathrm{p}_{\mathrm{a}} \mathrm{O}_{2}$, arterial partial pressure of oxygen; ROS, reactive oxygen species; OS, oxidative stress; HIE, hypoxic-ischemic encephalopathy; IsoPs, isoprostanes; COX, cyclooxygenase; AA, arachidonic acid; NeuroPs, neuroprostanes; DHA, docosahexaenoic acid; AdA, adrenic acid; IsoFs, isofurans; NeuroFs, neurofurans; PGs, prostaglandins; NAC, N-acetylcysteine; QC, quality control.

* Corresponding author.

E-mail address: julia.kuligowski@uv.es (J. Kuligowski). 
Lipid peroxidation

Ultra-performance liquid chromatography

coupled to tandem mass spectrometry

Plasma

Hypoxic-ischemic encephalopathy

Newborn the quantitative analysis of isoprostanoids was critically compared to that provided by a previously developed approach aiming at the semi-quantitative detection of total parameters of fatty acid derived lipid peroxidation biomarkers.

\section{Introduction}

Fetal life develops in a relatively hypoxic environment with an in utero arterial partial pressure of oxygen $\left(\mathrm{p}_{\mathrm{a}} \mathrm{O}_{2}\right)$ of approximately $3.3 \mathrm{kPa}$. After birth and with the initiation of spontaneous respiratory alveolar-capillary gas exchange, the situation changes abruptly and $\mathrm{p}_{\mathrm{a}} \mathrm{O}_{2}$ saturation in the circulating blood stream rises to approximately $10.5 \mathrm{kPa}$ within the first minutes of life [1]. During the fetal-to-neonatal transition, a burden of reactive oxygen species (ROS) causes physiologic oxidative stress (OS) essential for the activation of specific metabolic pathways which enable an adequate adaptation to the extra-uterine environment [2].

Perinatal asphyxia is characterized by intermittent periods of hypoxia-ischemia and is considered an important cause of early neonatal death and severe neurological sequel such as hypoxicischemic encephalopathy (HIE) and cerebral palsy [3]. Both hypoxia and reoxygenation can generate ROS exceeding the levels observed under physiologic conditions during the fetal-to-neonatal transition which may react with non-radical macromolecules such as DNA, proteins and lipids [4]. OS appears to play a key role in neonatal brain damage, with the neonatal brain being especially susceptible because of its high concentration of unsaturated fatty acids, high rate of oxygen consumption, low concentration of antioxidants, and high iron levels [5].

Isoprostanes (IsoPs) are non-cyclooxygenase (COX) derived, prostaglandin-like molecules generated by the free radical-induced peroxidation of arachidonic acid (AA) [6]. Initially IsoPs are produced in esterified form attached to phospholipids, and then released into body fluids in free form. Today, they are considered the gold standard for in vivo assessment of lipid peroxidation due to their stability, selectivity and specificity [7-9]. Following similar mechanisms of non-enzymatic oxygenation, neuroprostanes (NeuroPs) and dihomo-IsoPs are generated from docosahexaenoic acid (DHA) and adrenic acid (AdA), respectively. In addition, when conditions switch to high oxygen tensions, isofurans (IsoFs) and neurofurans (NeuroFs) may be preferentially produced from AA and DHA, respectively $[10,11]$.

The role of lipid peroxidation in pathologies of the neonate has been reviewed $[12,13]$. It was found that preterm infants with high urinary IsoF levels in the first days after birth are more prone to develop chronic lung conditions such as bronchopulmonary dysplasia as compared to a control group [14]. In a preliminary case study, the potential of lipid peroxidation byproducts as biomarkers for HIE have been studied and significantly increased concentrations of IsoPs were found for newborns with severe postnatal acidemia [15].

Literature reports three primary analytical techniques for the determination of isoprostanoids in biological fluids and tissue extracts including (i) immunological methods such as radioimmunoassay and enzyme linked immunosorbent assay, (ii) gas chromatography coupled to mass spectrometry (MS) and (iii) liquid chromatography coupled to MS (LC-MS). Results obtained from immunoassays might be potentially biased due to the use of polyclonal antibodies and the high structural similarities between IsoPs and COX-derived prostaglandins as well as other related molecules. Furthermore this technique is intrinsically limited as it does not allow differentiation between isomers. In contrast, MS-based assays are widely accepted as the most accurate methodologies $[7,16,17]$. LC coupled to tandem MS (LC-MS/MS) presents interesting advantages over GC-MS. It does not require long derivatization processes thus reducing the possibility of introducing additional sources of error. Moreover, the use of Ultra-high Performance Liquid Chromatography tandem mass spectrometry (UPLC-MS/MS) involves rapid chromatographic separations. UPLC-MS/MS offers suitable selectivity and sensitivity combined with a high sample throughput for which it has gained popularity recently in this field, especially for clinical applications [14,18-21].

In clinical studies, the choice of the biological fluid is of major concern. Urine samples are suitable for a long-term survey of lipid peroxidation biomarkers of up to several days or weeks after an insult or intervention and allow repeated sampling, but the main pitfall is its limited time resolution and it might not be optimal when the objective is the analysis of early, fast responses in e.g. time-critical therapies. Conversely, blood reflects the dynamic metabolic response immediately improving time resolution. On the other hand, blood collection is an invasive procedure and the use of small volumes is mandatory, especially in the field of neonatology.

The objective of this work was the development and validation of a comprehensive analytical approach for isoprostanoids profiling in human plasma samples covering a broad range of lipid peroxidation product classes derived from AA, DHA and AdA. The method was developed to fulfill specific requirements to enable its clinical application in neonatology such as addressing the challenge of limited sample volumes, straightforward sample processing and high analytical throughput. In order to assess the usefulness of the developed method, it was employed for the analysis of 150 plasma samples collected from newborns. Information obtained from quantitative analysis was critically compared to that provided by a previously developed approach aiming at the semi-quantitative of total parameters of IsoPs, IsoFs, NeuroPs and NeuroFs, proposed as disease associated biomarkers in clinical applications.

\section{Material and methods}

\subsection{Standards and reagents}

Commercially available IsoPs (2,3-dinor- $15-\mathrm{F}_{2 \mathrm{t}}$-IsoP, 15 -keto-15-

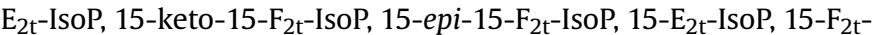
IsoP), prostaglandins (PGs) ( $\mathrm{PGE}_{2}, \mathrm{PGF}_{2 \alpha}, 2,3$-dinor-11 $\beta-\mathrm{PGF}_{2 \alpha}, 11 \beta-$ PGF2 $\alpha$, 6-keto-PGF $1 \alpha$ ), dihomo-PG (1a,1b-dihomo-PGF $2 \alpha$ ) were purchased from Cayman Chemical Company (Ann Arbor, MI, USA), with purities $\geq 95 \%$ as well as deuterated internal standards (IS, $\mathrm{PGF}_{2 \alpha}-\mathrm{d}_{4}$ and $15-\mathrm{F}_{2 \mathrm{t}}-\mathrm{IsoP}-\mathrm{d}_{4}$ ) with purities $\geq 98 \%$ and incorporation $\geq 99 \%$ deuterated form $\left(d_{1}-d_{4}\right) ;<1 \% d_{0}$.

Other analytical standards employed were $\mathrm{F}_{2}$-IsoPs $\left(5-\mathrm{F}_{2 \mathrm{t}}\right.$-IsoP, 5-epi-5- $\mathrm{F}_{2 \mathrm{t}}$-IsoP, 15-epi-2,3-dinor-15- $\mathrm{F}_{2 \mathrm{t}}$-IsoP), $\mathrm{F}_{4}-\mathrm{NeuroPs}\left(4-\mathrm{F}_{4 \mathrm{t}^{-}}\right.$

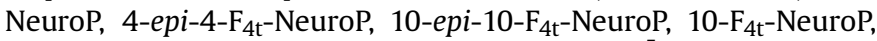
14(RS)-14- $\mathrm{F}_{4 \mathrm{t}}$-NeuroP), $\quad \mathrm{F}_{4}$-NeuroF (4(RS)-ST- $\left.\Delta^{5}-8-\mathrm{NeuroF}\right), \mathrm{F}_{2^{-}}$ dihomo-IsoPs (17-F $\mathrm{F}_{2 \mathrm{t}}$-dihomo-IsoP, 17-epi-17-F $\mathrm{F}_{2 \mathrm{t}}$-dihomo-IsoP, Ent$7(R S)-\mathrm{F}_{2 \mathrm{t}}$-dihomo-IsoP), and $\mathrm{F}_{2}$-dihomo-IsoFs (17(RS)-10-epi-SC$\Delta^{15}$-11-dihomo-IsoF, 7(RS)-ST- $\Delta^{8}$-11-dihomo-IsoF) synthesized at the Institut des Biomolecules Max Mosseron (Montpellier, France) 
Table 1

Characteristics of the studied population.

\begin{tabular}{ll}
\hline Variable & Value \\
\hline Male/female & $11 / 9$ \\
Mean gestational age $\pm \mathrm{s}$ (weeks) & $38.3 \pm 1.7$ \\
Mean birth weight $\pm \mathrm{s}(\mathrm{g})$ & $3290 \pm 460$ \\
Vaginal/C-section & $5 / 15$ \\
Mean cord $\mathrm{pH} \pm \mathrm{s}$ & $6.9 \pm 0.2$ \\
Mean base $\mathrm{excess} \pm \mathrm{s}\left(\mathrm{mEqL}^{-1}\right)$ & $-17.0 \pm 8.8$ \\
Mean lactate $\pm \mathrm{s}(\mathrm{mM})$ & $9.1 \pm 5.0$ \\
Mean Apgar score $\pm \mathrm{s}$ at $1 \mathrm{~min}$ & $1.2 \pm 1.2$ \\
Mean Apgar score $\pm \mathrm{s}$ at $5 \mathrm{~min}$ & $3.2 \pm 2.2$ \\
Mean Apgar score $\pm \mathrm{s}$ at $10 \mathrm{~min}$ & $5.5 \pm 2.2$ \\
\hline
\end{tabular}

according to previously published procedures [22-29], with purities $\geq 99 \%$ and all physical data reported in those published articles confirmed the new structures [22-29].

Potassium hydroxide $(\mathrm{KOH})$ was from Sigma Aldrich Química SA (Madrid, Spain). LC-MS grade solvents (methanol $\mathrm{CH}_{3} \mathrm{OH}$, ethanol, heptane and acetonitrile $\mathrm{CH}_{3} \mathrm{CN}$ ) were purchased from J.T. Baker (Phillipsburg, NJ, USA). Formic acid ( $\mathrm{HCOOH}, 98 \%)$ and ethyl acetate (analytical grade) were from Panreac (Barcelona, Spain). Ultrapure $\mathrm{H}_{2} \mathrm{O}$ was generated on a milliQ system from Merck Millipore (Darmstadt, Germany).

\subsection{Preparation of stock, working, and standard solutions}

Individual stock solutions of solid pure analytical standards at a concentration of $1 \mathrm{mmol} \mathrm{L}^{-1}$ were prepared in ethanol. Individual

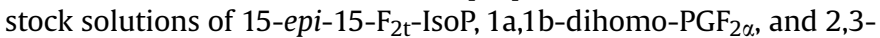
dinor-15- $\mathrm{F}_{2 \mathrm{t}}$-IsoP standards were purchased in methyl acetate or at concentrations of $2.8,2.6$ and $0.3 \mathrm{mmol} \mathrm{L}^{-1}$, respectively. A $5 \mu \mathrm{mol} \mathrm{L}{ }^{-1}$ working solution of the set of target analytes was prepared by mixing adequate volumes of the individual stock solutions followed by evaporation to dryness and dissolution in $\mathrm{H}_{2} \mathrm{O}(0.1 \% \mathrm{v} / \mathrm{v}$ $\mathrm{HCOOH}, \mathrm{pH} 3): \mathrm{CH}_{3} \mathrm{OH}(85: 15 \mathrm{v} / \mathrm{v})$. Likewise, an IS working solution containing both IS $\left(\mathrm{PGF}_{2 \alpha}-\mathrm{d}_{4}\right.$ and $\left.15-\mathrm{F}_{2 \mathrm{t}}-\mathrm{IsoP}-\mathrm{d}_{4}\right)$ at a concentration of $20 \mu \mathrm{mol} \mathrm{L}^{-1}$ each was prepared. Aliquots of the obtained stock and working solutions were stored in capped amber vials at $-20^{\circ} \mathrm{C}$ to avoid repeated freeze and thaw cycles. Standard solutions used for calibration were prepared on each measurement day from the working solution by serial dilution in $\mathrm{H}_{2} \mathrm{O}(0.1 \% \mathrm{v} / \mathrm{v} \mathrm{HCOOH}, \mathrm{pH}$ 3): $\mathrm{CH}_{3} \mathrm{OH}(85: 15 \mathrm{v} / \mathrm{v})$.

\subsection{Population}

After obtaining informed consent, twenty neonates $\geq 35$ weeks gestation with HIE who qualified for cooling were recruited in a dose-finding, phase 0 clinical trial of N-acetylcysteine (NAC) and $1,25(\mathrm{OH}) 2$ vitamin $\mathrm{D}$ (calcitriol). This study was approved by the Institutional Review Board at the Medical University of South Carolina, Charleston. Neonates with stage 2 or 3 HIE were enrolled within $6 \mathrm{~h}$ of birth. They received hypothermia $\left(33^{\circ} \mathrm{C}\right.$ rectal temperature) for $72 \mathrm{~h}$ and intravenous administration of NAC 25 or $40 \mathrm{mg} / \mathrm{kg}$ by infusion over $1 \mathrm{~h}, \mathrm{q} 12 \mathrm{~h}$, and calcitriol $0.05 \mathrm{mcg} / \mathrm{kg} \mathrm{q}$ $12 \mathrm{~h}$ from enrollment (3-6 h of age) until discharge or 10 days of life. Due to elevated ionized calcium in several subjects, calcitriol dose was decreased to $0.03 \mathrm{mcg} / \mathrm{kg} \mathrm{q} 24 \mathrm{~h}$ for subjects $11-20$. Characteristics of the HIE neonates are presented in Table 1.

Blood was collected in sodium EDTA tubes, centrifuged, and plasma was frozen at $-80{ }^{\circ} \mathrm{C}$ within $15-20 \mathrm{~min}$ of collection. Samples were obtained before, and $0.5 \mathrm{~h}, 1 \mathrm{~h}$ and $11.5 \mathrm{~h}$ after the $1 \mathrm{st}$

Table 2

Acquisition parameters and main figures of merit of the LC-MS/MS method.

\begin{tabular}{|c|c|c|c|c|c|c|c|c|c|c|c|}
\hline$\#^{\mathrm{a}}$ & Analyte & $\begin{array}{l}m / z \text { Parent } \\
\text { ion }\end{array}$ & $\begin{array}{l}\text { Cone } \\
{[\mathrm{V}]}\end{array}$ & $\begin{array}{l}\mathrm{CE} \\
{[\mathrm{eV}]}\end{array}$ & $\begin{array}{l}m / z \text { Daughter } \\
\text { Ions }\end{array}$ & $\begin{array}{l}\mathrm{RT} \pm \mathrm{S} \\
(\mathrm{min})\end{array}$ & $\begin{array}{l}\text { Calibration range } \\
(\mathrm{nM})\end{array}$ & $\mathrm{R}^{2}$ & $\begin{array}{l}\text { LOD } \\
(\mathrm{nM})\end{array}$ & $\begin{array}{l}\text { LOQ } \\
(\mathrm{nM})\end{array}$ & $\begin{array}{l}\text { Internal } \\
\text { standard }\end{array}$ \\
\hline 1 & 5- $\mathrm{F}_{2 \mathrm{t}}$-IsoP $+5-e p i-5-\mathrm{F}_{2 \mathrm{t}}$-IsoP & 353.20 & 35 & 30 & 115.00 & $5.09 \pm 0.03$ & $3.5-3562.5$ & 0.991 & 0.6 & 2 & $\mathrm{PGF}_{2 \alpha}-\mathrm{d} 4$ \\
\hline 2 & $\begin{array}{l}\text { 15-epi-2,3-dinor-15-F } \mathrm{F}_{2 \mathrm{t}} \text {-IsoP }+ \\
\text { 2,3-dinor-11 } 1-\mathrm{PGF}_{2 \alpha}+ \\
\text { 2,3-dinor-15- } \mathrm{F}_{2 \alpha} \text {-IsoP }\end{array}$ & 325.27 & 40 & 13 & 237.00 & $3.71 \pm 0.04$ & $1.7-3562.5$ & 0.998 & 0.3 & 1.0 & 15-F2t-IsoP-d4 \\
\hline 12 & $\begin{array}{l}\text { 4-F } 4 \mathrm{t}-\mathrm{NeuroP}+ \\
4-e p i-4-\mathrm{F}_{4 \mathrm{t}}-\mathrm{NeuroP}\end{array}$ & 377.32 & 20 & 19 & 271.12 & $5.70 \pm 0.03$ & $1.7-3562.5$ & 0.996 & 0.3 & 1.0 & $\mathrm{PGF}_{2 \alpha}-\mathrm{d} 4$ \\
\hline 13 & 10-epi-10-F $\mathrm{F}_{4 \mathrm{t}}-$ NeuroP & 377.32 & 10 & 19 & 153.00 & $5.17 \pm 0.03$ & $0.6-1187.5$ & 0.994 & 0.11 & 0.4 & $\mathrm{PGF}_{2 \alpha}-\mathrm{d} 4$ \\
\hline 14 & $410-\mathrm{F}_{4 \mathrm{t}}-\mathrm{NeuroP}$ & 377.32 & 10 & 19 & 153.00 & $5.02 \pm 0.03$ & $0.6-1187.5$ & 0.998 & 0.11 & 0.4 & 15-F2t-IsoP-d4 \\
\hline 15 & $14(R S)-14-\mathrm{F}_{4 \mathrm{t}}-$ NeuroP & 377.32 & 50 & 19 & 204.89 & $5.33 \pm 0.03$ & $9.3-1187.5$ & 0.993 & 2 & 6 & $\mathrm{PGF}_{2 \alpha}-\mathrm{d} 4$ \\
\hline 16 & $4(R S)-\mathrm{ST}-\Delta^{5}-8$-NeuroF & 393.60 & 40 & 35 & 123.19 & $5.78 \pm 0.03$ & $296.9-4750$ & 0.973 & 53 & 178 & $\mathrm{PGF}_{2 \alpha}-\mathrm{d} 4$ \\
\hline 17 & $\begin{array}{l}\text { 17-F }{ }_{2 t} \text {-dihomo-IsoP }+17-e p i-17-F_{2 t}-\text { dihomo- } \\
\text { IsoP }\end{array}$ & 381.30 & 20 & 25 & 337.15 & $5.80 \pm 0.02$ & $1.2-2375$ & 0.997 & 0.2 & 0.7 & $\mathrm{PGF}_{2 \alpha}-\mathrm{d} 4$ \\
\hline 19 & ent-7(RS)- $\mathrm{F}_{2 \mathrm{t}}$-dihomo-IsoP & 381.30 & 50 & 25 & 142.98 & $5.83 \pm 0.02$ & $0.6-1187.5$ & 0.990 & 0.11 & 0.4 & $\mathrm{PGF}_{2 \alpha}-\mathrm{d} 4$ \\
\hline 20 & $17(R S)$-10-epi-SC- $\Delta^{15}$-11-dihomo-IsoF & 397.40 & 20 & 31 & 155.02 & $6.06 \pm 0.01$ & $0.6-1187.5$ & 0.994 & 0.11 & 0.4 & $\mathrm{PGF}_{2 \alpha}-\mathrm{d} 4$ \\
\hline 21 & $7(R S)-$ ST- $\Delta^{8}-11$-dihomo-IsoF & 397.40 & 40 & 25 & 201.03 & $6.06 \pm 0.01$ & $148.4-4750$ & 0.984 & 27 & 89 & $\mathrm{PGF}_{2 \alpha}-\mathrm{d} 4$ \\
\hline 3 & 15-keto-15-F ${ }_{2 t}$-IsoP & 351.00 & 35 & 25 & 289.00 & $5.13 \pm 0.04$ & $1.2-1187.5$ & 0.995 & 0.2 & 0.7 & $\mathrm{PGF}_{2 \alpha}-\mathrm{d} 4$ \\
\hline 18 & 1a,1b-dihomo-PGF $2 \alpha$ & 381.30 & 20 & 25 & 337.15 & $6.01 \pm 0.01$ & $1.2-1187.5$ & 0.994 & 0.2 & 0.7 & $15-\mathrm{F} 2 \mathrm{t}-\mathrm{IsoP}-\mathrm{d} 4$ \\
\hline 5 & $15-\mathrm{F}_{2 \mathrm{t}}$-IsoP & 353.00 & 35 & 30 & 193.00 & $4.83 \pm 0.03$ & $2.3-1187.5$ & 0.997 & 0.4 & 1.4 & 15-F2t-IsoP-d4 \\
\hline 8 & $15-E_{2 t}$-IsoP & 351.00 & 35 & 30 & 271.00 & $5.35 \pm 0.03$ & $9.2-1187.5$ & 0.990 & 2 & 6 & $\mathrm{PGF}_{2 \alpha}-\mathrm{d} 4$ \\
\hline 6 & $11 \beta-\mathrm{PGF}_{2 \alpha}$ & 353.00 & 35 & 30 & 193.00 & $4.93 \pm 0.03$ & $1.2-1187.5$ & 0.998 & 0.2 & 0.7 & 15-F2t-IsoP-d4 \\
\hline 4 & $15-e p i-15-\mathrm{F}_{2 \mathrm{t}}$-IsoP & 353.00 & 35 & 30 & 193.00 & $4.76 \pm 0.03$ & $2.3-1187.5$ & 0.998 & 0.4 & 1.4 & 15-F2t-IsoP-d4 \\
\hline 10 & 6-keto-PGF $1 \alpha$ & 369.00 & 40 & 35 & 245.00 & $3.97 \pm 0.03$ & $0.6-1187.5$ & 0.997 & 0.11 & 0.4 & 15-F2t-IsoP-d4 \\
\hline 7 & $\mathrm{PGF}_{2 \alpha}$ & 353.00 & 35 & 30 & 193.00 & $5.24 \pm 0.03$ & $0.6-1187.5$ & 0.993 & 0.11 & 0.4 & $\mathrm{PGF}_{2 \alpha}-\mathrm{d} 4$ \\
\hline 11 & 15-keto-15-E $\mathrm{E}_{2 \mathrm{t}}$-IsoP & 349.00 & 40 & 30 & 113.00 & $5.73 \pm 0.03$ & $2.3-1187.5$ & 0.996 & 0.4 & 1.4 & $\mathrm{PGF}_{2 \alpha}-\mathrm{d} 4$ \\
\hline 9 & $\mathrm{PGE}_{2}$ & 351.00 & 35 & 30 & 271.00 & $5.42 \pm 0.04$ & $2.3-1187.5$ & 0.992 & 0.4 & 1.4 & $\mathrm{PGF}_{2 \alpha}-\mathrm{d} 4$ \\
\hline 22 & $\mathrm{PGF}_{2 \alpha}-\mathrm{d}_{4}$ & 357.00 & 40 & 30 & 197.00 & $5.24 \pm 0.03$ & - & - & - & - & - \\
\hline 23 & $15-\mathrm{F}_{2 \mathrm{t}}-\mathrm{IsoP}-\mathrm{d}_{4}$ & 357.00 & 40 & 30 & 197.00 & $4.81 \pm 0.03$ & - & - & - & - & - \\
\hline- & Isoprostanes & 353.20 & 35 & 30 & 115.00 & $4.0-6.3$ & - & - & - & - & $\mathrm{PGF}_{2 \alpha}-\mathrm{d} 4$ \\
\hline- & Isofurans & 369.20 & 45 & 20 & 115.00 & $1.9-6.3$ & - & - & - & - & $\mathrm{PGF}_{2 \alpha}-\mathrm{d} 4$ \\
\hline- & Neuroprostanes & 377.00 & 35 & 20 & 101.00 & $2.0-6.2$ & - & - & - & - & $\mathrm{PGF}_{2 \alpha}-\mathrm{d} 4$ \\
\hline- & Neurofurans & 393.00 & 35 & 20 & 193.00 & $2.4-6.2$ & - & - & - & - & $\mathrm{PGF}_{2 \alpha}-\mathrm{d} 4$ \\
\hline
\end{tabular}

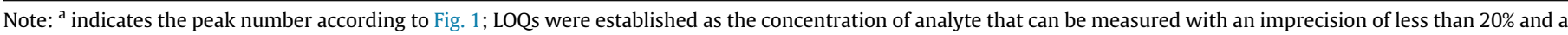
deviation from target of less than $20 \%$ and taking into account the preconcentration factor achieved during sample processing. The LOD is defined as $3 / 10 *$ LOQ. 
dose, and peak samples $1 \mathrm{~h}$ after the 3rd (24-30 h) dose during hypothermia. A second set of blood samples were obtained during normothermia before, and $0.5 \mathrm{~h}, 1 \mathrm{~h}$ and $11.5 \mathrm{~h}$ after the 10th or 11th NAC dose on day of life 5-6 ( $>24 \mathrm{~h}$ after rewarming). Aliquots of plasma remained frozen at $-80^{\circ} \mathrm{C}$, and shipped on dry ice without thawing until analysis.

\subsection{Processing of plasma samples}

Samples were processed following previously described methods [14,18,19,30,31] with slight modifications. Briefly, $100 \mu \mathrm{L}$ of plasma were thawed on ice, homogenized and $3 \mu \mathrm{L}$ of IS working solution $\left(20 \mu \mathrm{mol} \mathrm{L}^{-1}\right)$ were added. For basic hydrolysis $100 \mu \mathrm{L}$ of $\mathrm{KOH}(15 \% \mathrm{w} / \mathrm{v})$ were added to each sample followed by incubation for $30 \mathrm{~min}$ at $40{ }^{\circ} \mathrm{C}$ with gentle agitation in a WSB- 18 water bath from Witeg (Wertheim, Germany). Thereafter, samples were diluted with $700 \mu \mathrm{L}$ of $\mathrm{H}_{2} \mathrm{O}: \mathrm{CH}_{3} \mathrm{OH}: \mathrm{HCOOH}(82.6: 14.6: 2.8 \mathrm{v} / \mathrm{v}$ ), homogenized on a Vortex mixer for $5 \mathrm{~s}$ and kept on ice for $10 \mathrm{~min}$ followed by centrifugation at $16000 \times g$ for $10 \mathrm{~min}$ at $4{ }^{\circ} \mathrm{C}$.

Solid phase extraction (SPE) employing Discovery ${ }^{\circledR}$ DSC-18 SPE 96-well plates from Sigma-Aldrich (St. Louis, MO, USA) was carried out as follows: SPE cartridges were conditioned with $1 \mathrm{~mL} \mathrm{CH} \mathrm{H}_{3} \mathrm{OH}$ followed by $1 \mathrm{~mL} \mathrm{H} \mathrm{H}_{2} \mathrm{O}(0.1 \% \mathrm{v} / \mathrm{v} \mathrm{HCOOH}, \mathrm{pH}$
3) and then diluted samples were loaded into the SPE wells. The washing steps included rinsing of each well with $1 \mathrm{~mL} \mathrm{H}_{2} \mathrm{O}$ $(0.1 \% \mathrm{v} / \mathrm{v} \mathrm{HCOOH}, \mathrm{pH} 3)$ and $500 \mu \mathrm{L}$ heptane. Cartridges were dried with room air and sample extracts were eluted with $4 \times 100 \mu \mathrm{L}$ ethyl acetate which were subsequently evaporated using a miVac centrifugal vacuum concentrator from Genevac LTD (Ipswich, UK). Sample extracts were dissolved in $60 \mu \mathrm{L}$ of $\mathrm{H}_{2} \mathrm{O}(0.1 \% \mathrm{v} / \mathrm{v} \mathrm{HCOOH}, \mathrm{pH} 3): \mathrm{CH}_{3} \mathrm{OH}(85: 15 \mathrm{v} / \mathrm{v})$ prior to UPLCMS/MS analysis.

\subsection{UPLC-MS/MS analysis}

UPLC-MS/MS analysis was carried out employing an AcquityXevo TQS system from Waters (Milford, MA, USA) using negative electrospray ionization $\left(\mathrm{ESI}^{-}\right)$. Instrumental conditions were selected as follows: capillary voltage was set to $2.9 \mathrm{kV}$, source temperature was $150{ }^{\circ} \mathrm{C}$, desolvation temperature was $395{ }^{\circ} \mathrm{C}$ and nitrogen cone and desolvation gas flows were set to 150 and $800 \mathrm{~L} \mathrm{~h}^{-1}$, respectively. Dwell time was set to ensure a minimum of 10 data points per peak. Separation conditions were selected to achieve appropriate chromatographic retention and resolution by using a Waters BEH C18 reversed phase column $(2.1 \times 100 \mathrm{~mm}$, $1.7 \mu \mathrm{m})$ and $\mathrm{a} \mathrm{H}_{2} \mathrm{O}(0.1 \% \mathrm{v} / \mathrm{v} \mathrm{HCOOH}): \mathrm{CH}_{3} \mathrm{CN}(0.1 \% \mathrm{v} / \mathrm{v} \mathrm{HCOOH})$
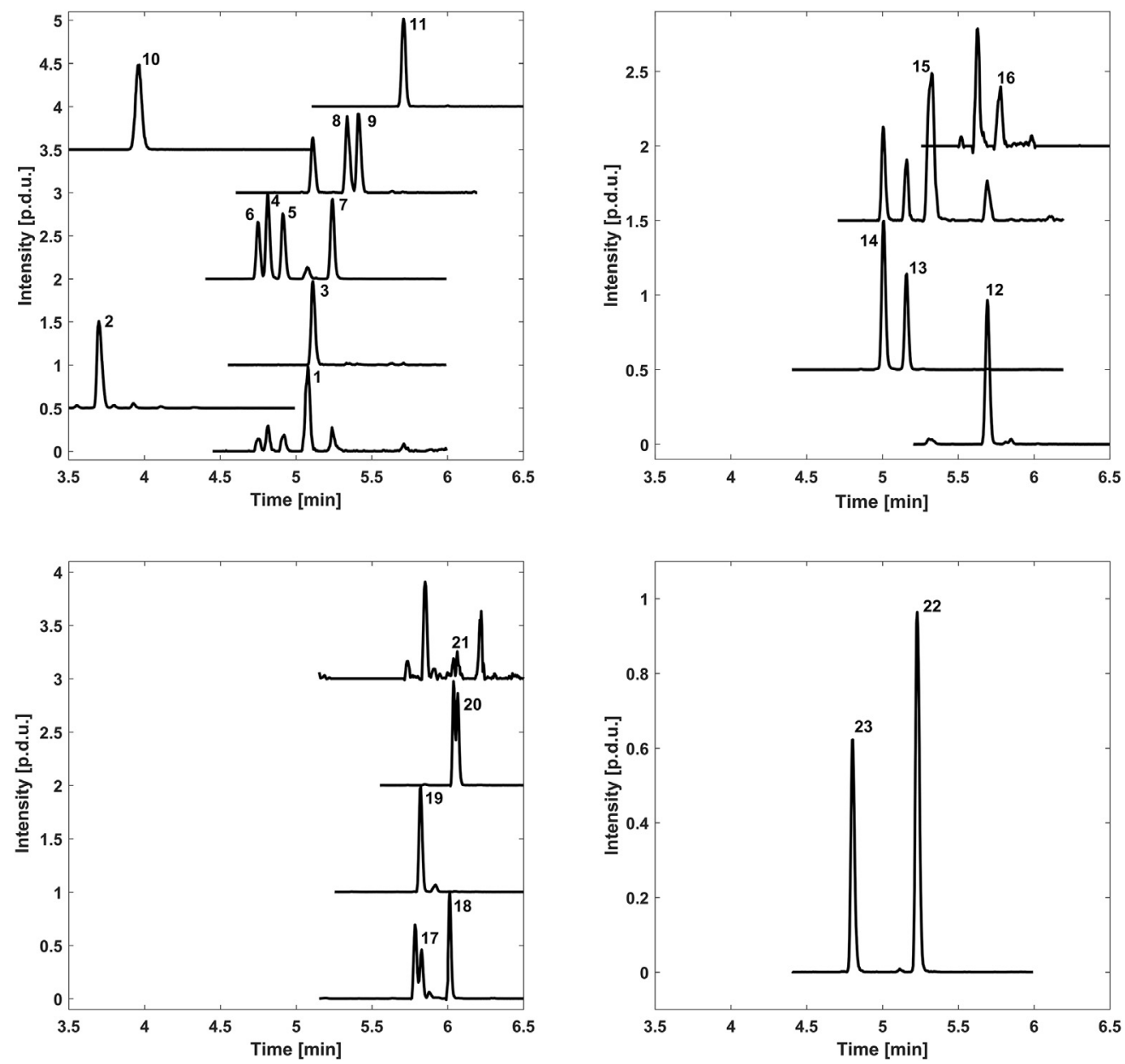

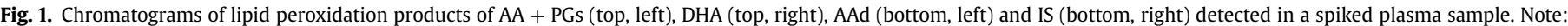

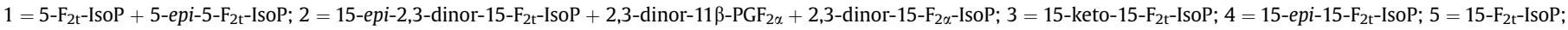

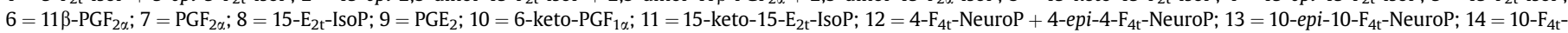

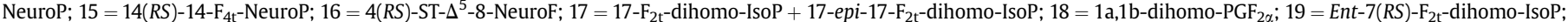

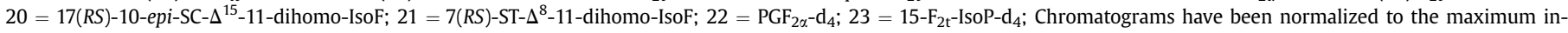
tensity of the highest detected peak; chromatograms have been shifted in the y-direction for a better visibility. 
binary gradient. Flow rate, column temperature and injection volume were set at $450 \mu \mathrm{L} \mathrm{m^{-1 }}, 45^{\circ} \mathrm{C}$ and $9 \mu \mathrm{L}$, respectively. The gradient with a total run time of $7.0 \mathrm{~min}$ was as follows: from 0.0 to $0.1 \mathrm{~min} 15 \% \mathrm{v} / \mathrm{v} \mathrm{CH} \mathrm{CH}_{3} \mathrm{CN}(0.1 \% \mathrm{v} / \mathrm{v} \mathrm{HCOOH})$ (i.e. channel B); from 0.1 to $5.0 \mathrm{~min} \% \mathrm{~B}$ increased up to $40 \%$; from 5.0 to $6.0 \mathrm{~min} \% \mathrm{~B}$ increased up to $75 \%$; between 6.0 and 6.15 conditions were held constant at $75 \%$ B followed by the return to initial conditions (i.e. $15 \%$ B) between 6.15 and $6.25 \mathrm{~min}$; conditions were maintained for $0.75 \mathrm{~min}$ for system re-equilibration.

MS detection was carried out by multiple reaction monitoring (MRM) employing the acquisition parameters summarized in Table 2. The UPLC-MS/MS system was operated employing MassLynx software version 4.0 from Waters. Cone voltages and collision energy values were optimized by analysis of individual $1 \mu \mathrm{M}$ standard solutions in the UPLC-ESI-MS/MS system. For quantification, linear regression curves with $1 / \mathrm{x}$ weighting were calculated including signal normalization with an IS. Concentrations found in plasma samples falling outside the calibration range or showing a shift in retention time bigger than $\pm 0.05 \mathrm{~min}$ in comparison to standard solutions were not further considered. For total parameters (total IsoPs, IsoFs, NeuroPs and NeuroFs), MRM detection was carried out as previously described [14]. Here, relative signal intensities normalized using the IS signal were determined instead of absolute concentrations in order to avoid the need of pure analytical standards. Total parameters were considered when the area was $>3$ times the signal of a blank.

On each measurement day, prior to the launch of the analytical sequence, a system suitability test was carried out including the following criteria: (i) a backpressure ripple $<2 \%$ at the beginning of the chromatographic run; (ii) absence of the IS peak in a non-spiked plasma sample; (iii) absence of analyte peaks during a blank injection (i.e. $\mathrm{H}_{2} \mathrm{O}(0.1 \% \mathrm{v} / \mathrm{v} \mathrm{COOH})$ ); (iv) appropriate sensitivity and precision during triplicate analysis of a standard solution at the LOQ. Accordingly, \%RSD of peak area values should be $\leq 25 \%$ and the signal-to-noise ratios $\geq 9$ for each studied analyte; and (v) retention times within \pm 0.05 min between consecutive batches.
Blank samples and solvent blanks were analyzed at the beginning of the sample batch, after a high concentration standard and repeatedly along the batch in order to check for contamination of the analytical system (i.e. column, mobile phase additives etc.), carryover and cross contamination. A representative quality control (QC) plasma sample was analyzed repeatedly throughout sample batches to detect deviations in accuracy and/or precision. An analysis batch was accepted if at least $75 \%$ of the values found for the QC standards were within $\pm 25 \%$ of their respective nominal values.

\subsection{Method validation}

During method validation, figures of merit of the sample preparation and measurement procedure including the linearity range, precision, accuracy, selectivity, limit of detection (LOD), limit of quantification (LOQ) and carry-over were assessed. The method validation was based on the US Food and Drug Administration (FDA) guidelines for bioanalytical method validation [32]. However, the FDA guideline aims at the quantitative analysis of drugs and drug metabolites in biological matrices and it cannot be directly applied to the analysis of endogenous metabolites due to the lack of blank matrices. To circumvent this, accuracy and precision of the method were established by calculating relative recovery values. Therefore, a non-spiked pooled plasma sample was analyzed by triplicate on each validation day. Duplicate analysis of standards at three concentration levels and triplicate analysis of plasma samples spiked before and after SPE at two concentration levels on two measurement days were carried out. The percentage of relative standard deviation (RSD) of replicate standards within one validation batch (intra-day) and between validation batches (inter-day) were calculated to assess precision. Inter-day and intraday extraction yields were calculated comparing absolute peak areas from samples spiked before and after SPE and the matrix effect was determined by comparing absolute peak areas of samples spiked after SPE to pure analytical standards. Furthermore, the

Table 3

Back-calculated intra- and inter-day accuracy and precision of standard solutions.

\begin{tabular}{|c|c|c|c|c|c|c|c|}
\hline \multirow[t]{3}{*}{$\#^{\mathrm{a}}$} & \multirow[t]{3}{*}{ Analyte } & \multicolumn{6}{|c|}{ Standard solutions - \% Accuracy \pm RSD (conc nM) } \\
\hline & & \multicolumn{3}{|l|}{ Intra-day $(\mathrm{N}=3)$} & \multicolumn{3}{|l|}{ Inter-day $(\mathrm{N}=2)$} \\
\hline & & Low & Medium & High & Low & Medium & High \\
\hline 1 & $5-\mathrm{F}_{2 \mathrm{t}}$-IsoP + 5-epi-5- $\mathrm{F}_{2 \mathrm{t}}$-IsoP & $96 \pm 6(3.5)$ & $110 \pm 10(111.3)$ & $98 \pm 9(3562.5)$ & $100.6 \pm 7(3.5)$ & $107 \pm 9(111.3)$ & $100 \pm 7(3562.5)$ \\
\hline 2 & $\begin{array}{l}\text { 15-epi-2,3-dinor-15-F } 2 \text {-IsoP }+ \\
\text { 2,3-dinor-11 } \beta-\text { PGF }_{2 \alpha}+ \\
\text { 2,3-dinor-15-F }{ }_{2 \alpha} \text {-IsoP }\end{array}$ & $89 \pm 4(1.7)$ & $108 \pm 2(111.3)$ & $101.8 \pm 8(3562.5)$ & $93 \pm 15(1.7)$ & $115 \pm 8(111.3)$ & $98 \pm 5(3562.5)$ \\
\hline 12 & $\begin{array}{l}4-\mathrm{F}_{4 \mathrm{t}}-\mathrm{NeuroP}+ \\
4-\text { epi-4-F } \mathrm{F}_{4 \mathrm{t}}-\mathrm{NeuroP}\end{array}$ & $80 \pm 8(1.7)$ & $105 \pm 5(111.3)$ & $97 \pm 1(3562.5)$ & $82.6 \pm 8(1.7)$ & $105 \pm 5(111.3)$ & $98 \pm 2(3562.5)$ \\
\hline 13 & 10-epi-10-F $\mathrm{F}_{4 \mathrm{t}}-\mathrm{NeuroP}$ & $110 \pm 10(0.6)$ & $99.3 \pm 5(37.1)$ & $101 \pm 8(1187.5)$ & $111 \pm 9(0.6)$ & $96 \pm 5(37.1)$ & $104 \pm 7(1187.5)$ \\
\hline 14 & $10-\mathrm{F}_{4 \mathrm{t}}-$ NeuroP & $112 \pm 12(0.6)$ & $103 \pm 10(37.1)$ & $100 \pm 5(1187.5)$ & $120 \pm 14(0.6)$ & $100 \pm 8(37.1)$ & $101.9 \pm 7(1187.5)$ \\
\hline 15 & $14(R S)-14-\mathrm{F}_{4 \mathrm{t}}-$ NeuroP & $110 \pm 20(9.3)$ & $99 \pm 2(148.4)$ & $98 \pm 12(1187.5)$ & $109.4 \pm 15(9.3)$ & $95 \pm 7(148.4)$ & $102 \pm 8(1187.5)$ \\
\hline 16 & $4(R S)-\mathrm{ST}-\Delta^{5}-8$-NeuroF & $107 \pm 10(296.9)$ & $95 \pm 15(1187.5)$ & $94 \pm 7(4750)$ & $109 \pm 6(296.9)$ & $85 \pm 14(1187.5)$ & $100 \pm 13(4750)$ \\
\hline 17 & $17-\mathrm{F}_{2 \mathrm{t}}$-dihomo-IsoP $+17-e p i-17-\mathrm{F}_{2 \mathrm{t}}$-dihomo-IsoP & $90 \pm 14(1.2)$ & $97 \pm 6(74.2)$ & $101 \pm 3(2375)$ & $103 \pm 12(1.2)$ & $95 \pm 1(74.2)$ & $103 \pm 3(2375)$ \\
\hline 19 & ent-7(RS)- $\mathrm{F}_{2 \mathrm{t}}$-dihomo-IsoP & $86 \pm 20(0.6)$ & $98 \pm 10(37.1)$ & $101 \pm 13(1187.5)$ & $99.1 \pm 11(0.6)$ & $98 \pm 7(37.1)$ & $101.8 \pm 9(1187.5)$ \\
\hline 20 & $17(R S)-10$-epi-SC- $\Delta^{15}$-11-dihomo-IsoF & $120 \pm 20(0.6)$ & $87 \pm 8(37.1)$ & $107 \pm 14(1187.5)$ & $130 \pm 17(0.6)$ & $86 \pm 5(37.1)$ & $106 \pm 9(1187.5)$ \\
\hline 21 & $7(R S)-$ ST- $\Delta^{8}$-11-dihomo-IsoF & $88 \pm 15(148.4)$ & $88 \pm 13(1187.5)$ & $112 \pm 12(4750)$ & $95 \pm 15(148.4)$ & $85 \pm 12(1187.5)$ & $104 \pm 11(4750)$ \\
\hline 3 & 15-keto-15- $\mathrm{F}_{2 \mathrm{t}}$-IsoP & $99.1 \pm 18(1.2)$ & $106 \pm 5(37.1)$ & $98 \pm 3(1135.2)$ & $103 \pm 20(1.2)$ & $104 \pm 5(5.1)$ & $100 \pm 4(1187.5)$ \\
\hline 18 & 1a,1b-dihomo-PGF $2 \alpha$ & $108 \pm 20(1.2)$ & $80 \pm 10(10)$ & $106 \pm 1(1187.5)$ & $118 \pm 15(1.2)$ & $81 \pm 6(37.1)$ & $107 \pm 3(1187.5)$ \\
\hline 5 & $15-\mathrm{F}_{2 \mathrm{t}}$-IsoP & $108 \pm 18(2.3)$ & $108 \pm 6(37.1)$ & $102 \pm 4(1187.5)$ & $90 \pm 20(1.2)$ & $107 \pm 4(37.1)$ & $100 \pm 4(1187.5)$ \\
\hline 8 & $15-\mathrm{E}_{2 \mathrm{t}}$-IsoP & $88 \pm 2(9.3)$ & $97 \pm 3(74.2)$ & $101 \pm 4(1187.5)$ & $100 \pm 20(1.2)$ & $102 \pm 20(74.2)$ & $100 \pm 3(1187.5)$ \\
\hline 6 & $11 \beta-\mathrm{PGF}_{2 \alpha}$ & $103 \pm 1(1.2)$ & $100 \pm 2(37.1)$ & $103 \pm 3(1187.5)$ & $93 \pm 12(1.2)$ & $104 \pm 5(37.1)$ & $100 \pm 3(1187.5)$ \\
\hline 4 & 15-epi-15-F ${ }_{2 t}$-IsoP & $115 \pm 1(2.3)$ & $101 \pm 7(74.2)$ & $100 \pm 2(1187.5)$ & $115 \pm 17(2.3)$ & $100 \pm 7(74.2)$ & $101 \pm 2(1187.5)$ \\
\hline 10 & 6-keto-PGF $1 \alpha$ & $82 \pm 6(0.6)$ & $101 \pm 3(37.1)$ & $102 \pm 1(1187.5)$ & $84 \pm 15(0.6)$ & $105 \pm 5(37.1)$ & $100 \pm 3(1187.5)$ \\
\hline 7 & $\mathrm{PGF}_{2 \alpha}$ & $112 \pm 8(9.3)$ & $100 \pm 1(148.4)$ & $97 \pm 2(1187.5)$ & $120 \pm 12(9.3)$ & $97 \pm 3(148.4)$ & $99 \pm 3(1187.5)$ \\
\hline 11 & 15-keto-15-E 2 -IsoP & $118 \pm 9(2.3)$ & $102 \pm 3(74.2)$ & $102 \pm 4(1187.5)$ & $110 \pm 20(2.3)$ & $104 \pm 5(74.2)$ & $100 \pm 4(1187.5)$ \\
\hline 9 & $\mathrm{PGE}_{2}$ & $90 \pm 12(2.3)$ & $98 \pm 4(74.2)$ & $98 \pm 2(1187.5)$ & $88 \pm 8(2.3)$ & $102 \pm 15(74.2)$ & $97 \pm 2(1187.5)$ \\
\hline
\end{tabular}

Note: Values within brackets indicate the concentration of each metabolite in the standard solution; ${ }^{a}$ indicates the peak number according to Fig. 1. 
method's overall accuracy and precision for the determination of the studied compounds in plasma were evaluated at two concentration levels by comparing the relative response of spiked samples and pure analytical standards. The LOD and LOQ levels were estimated as the concentrations providing a signal-to-noise ratio of 3 and 10, respectively also providing precision and accuracy levels within the FDA recommended ranges. Selectivity was evaluated by analyzing blanks and a non-spiked pooled plasma sample. The carry-over was determined from the analysis of a blank sample after to the measurement of a concentrated standard solution.

\section{Results and discussion}

\subsection{UPLC-MS/MS method for the determination of lipid peroxidation biomarkers}

Ionization and fragmentation conditions for the MS/MS quantification for the set of 28 analytical standards were optimized by analysis of $5 \mu \mathrm{mol} \mathrm{L}^{-1}$ individual standard solutions. Chemical structures of the studied compounds are shown in Supplementary Material Fig. 1 and the selected MS/MS acquisition parameters are summarized in Table 2. Chromatographic conditions were also optimized employing a $5 \mu \mathrm{mol} \mathrm{L}{ }^{-1}$ working solution. Specificity of the MRM transitions was assessed by analyzing a set of individual standards employing the proposed LC-MS/MS procedure, which included the recording of 16 MRM transitions. Fig. 1 displays representative LC-MS/MS chromatograms extracted from the analysis of a spiked plasma sample. As shown in the figure, symmetric peak shapes were obtained for the total of 23 resolved peaks, all eluting in a retention time window between 3.71 and $6.06 \mathrm{~min}$. Nonetheless, due to high structural similarities, a reduced number of lipids showed a significant chromatographic and MS overlap that could not be resolved neither by MS/MS nor by changing the chromatographic conditions (see Table 2).

Table 2 summarizes the main analytical figures of merit obtained for the quantification of the selected set of compounds. Highly reproducible retention times with a standard deviations $\leq 0.04 \mathrm{~min}$ were observed for the set of metabolites and IS. Linear calibration lines calculated using either $\mathrm{PGF}_{2 \alpha}-\mathrm{d}_{4}$ or $15-\mathrm{F}_{2 \mathrm{t}}-\mathrm{IsoP}-\mathrm{d}_{4}$

Table 4

Back-calculated intra- and inter-day accuracy and precision in spiked plasma samples.

\begin{tabular}{|c|c|c|c|c|c|c|c|c|c|c|c|c|c|}
\hline \multirow[t]{3}{*}{$\#^{\mathrm{a}}$} & \multirow[t]{3}{*}{ Analyte } & \multicolumn{4}{|c|}{$\begin{array}{l}\text { Extraction yield } \\
\text { Accuracy } \pm \text { RSD (conc nM) }\end{array}$} & \multicolumn{4}{|c|}{$\begin{array}{l}\text { Matrix effect } \\
\% \text { Accuracy } \pm \text { RSD (conc nM) }\end{array}$} & \multicolumn{4}{|c|}{$\begin{array}{l}\text { Method } \\
\text { Accuracy } \pm \text { RSD (conc nM) }\end{array}$} \\
\hline & & \multicolumn{2}{|c|}{ Intra-day $(\mathrm{N}=3)$} & \multicolumn{2}{|c|}{ Inter-day $(\mathrm{N}=2)$} & \multicolumn{2}{|c|}{ Intra-day $(\mathrm{N}=3)$} & \multicolumn{2}{|c|}{ Inter-day $(\mathrm{N}=2)$} & \multicolumn{2}{|c|}{ Intra-day $(\mathrm{N}=3)$} & \multicolumn{2}{|c|}{ Inter-day $(\mathrm{N}=2)$} \\
\hline & & Low & High & Low & High & Low & High & Low & High & Low & High & Low & High \\
\hline 1 & $5-\mathrm{F}_{2 \mathrm{t}}-\mathrm{IsoP}+5-e p i-5-\mathrm{F}_{2 \mathrm{t}}-\mathrm{IsoP}$ & $\begin{array}{l}104 \pm 13 \\
(15)\end{array}$ & $\begin{array}{l}91 \pm 14 \\
(1800)\end{array}$ & $\begin{array}{l}93 \pm 16 \\
(15)\end{array}$ & $\begin{array}{l}87 \pm 7 \\
(1800)\end{array}$ & $\begin{array}{l}83 \pm 11 \\
(15)\end{array}$ & $\begin{array}{l}86 \pm 13 \\
(1800)\end{array}$ & $\begin{array}{l}95 \pm 20 \\
(15)\end{array}$ & $\begin{array}{l}109 \pm 3 \\
(1800)\end{array}$ & $\begin{array}{l}110 \pm 4 \\
(15)\end{array}$ & $\begin{array}{l}105 \pm 4 \\
(1800)\end{array}$ & $\begin{array}{l}110 \pm 4 \\
(15)\end{array}$ & $\begin{array}{l}105 \pm 4 \\
(1800)\end{array}$ \\
\hline 2 & $\begin{array}{l}\text { 15-epi-2,3-dinor-15- } \mathrm{F}_{2 \mathrm{t}} \text {-IsoP }+ \\
\text { 2,3-dinor-11 } \beta \text {-PGF } 2 \alpha+ \\
\text { 2,3-dinor- } 15 \mathrm{~F}_{2 \alpha} \text {-IsoP }\end{array}$ & $\begin{array}{l}110 \pm 13 \\
(15)\end{array}$ & $\begin{array}{l}95 \pm 8 \\
(1800)\end{array}$ & $\begin{array}{l}98 \pm 17 \\
(15)\end{array}$ & $\begin{array}{l}93 \pm 2 \\
(1800)\end{array}$ & $\begin{array}{l}79 \pm 9 \\
(15)\end{array}$ & $\begin{array}{l}92 \pm 8 \\
(15)\end{array}$ & $\begin{array}{l}96 \pm 20 \\
(15)\end{array}$ & $\begin{array}{l}100 \pm 11 \\
(1800)\end{array}$ & $\begin{array}{l}95 \pm 3 \\
(15)\end{array}$ & $\begin{array}{l}95 \pm 4 \\
(1800)\end{array}$ & $\begin{array}{l}95 \pm 8 \\
(15)\end{array}$ & $\begin{array}{l}97 \pm 10 \\
(1800)\end{array}$ \\
\hline 12 & $\begin{array}{l}\text { 4-F4t-NeuroP }+ \\
4-e p i-4-\mathrm{F}_{4 \mathrm{t}}-\mathrm{NeuroP}\end{array}$ & $\begin{array}{l}89 \pm 12 \\
(15)\end{array}$ & $\begin{array}{l}103 \pm 18 \\
(1800)\end{array}$ & $\begin{array}{l}81 \pm 14 \\
(15)\end{array}$ & $\begin{array}{l}94 \pm 14 \\
(1800)\end{array}$ & $\begin{array}{l}100 \pm 15 \\
(15)\end{array}$ & $\begin{array}{l}89 \pm 17 \\
(1800)\end{array}$ & $\begin{array}{l}109 \pm 15 \\
(15)\end{array}$ & $\begin{array}{l}104 \pm 20 \\
(1800)\end{array}$ & $\begin{array}{l}109 \pm 5 \\
(15)\end{array}$ & $\begin{array}{l}119 \pm 7 \\
(1800)\end{array}$ & $\begin{array}{l}100 \pm 20 \\
(15)\end{array}$ & $\begin{array}{l}113 \pm 12 \\
(1800)\end{array}$ \\
\hline 13 & 10-epi-10-F 4 - - NeuroP & $\begin{array}{l}87 \pm 13 \\
(5)\end{array}$ & $\begin{array}{l}95 \pm 15 \\
(600)\end{array}$ & $81 \pm 9(5)$ & $\begin{array}{l}91 \pm 6 \\
(600)\end{array}$ & $\begin{array}{l}102 \pm 19 \\
(5)\end{array}$ & $\begin{array}{l}96 \pm 15 \\
(600)\end{array}$ & $\begin{array}{l}120 \pm 20 \\
(5)\end{array}$ & $\begin{array}{l}109 \pm 18 \\
(600)\end{array}$ & $\begin{array}{l}98 \pm 14 \\
(5)\end{array}$ & $\begin{array}{l}116 \pm 12 \\
(600)\end{array}$ & $\begin{array}{l}94 \pm 17 \\
(5)\end{array}$ & $\begin{array}{l}113 \pm 15 \\
(600)\end{array}$ \\
\hline 14 & $10-\mathrm{F}_{4 \mathrm{t}}-$ NeuroP & $\begin{array}{l}90 \pm 20 \\
(5)\end{array}$ & $\begin{array}{l}95 \pm 15 \\
(600)\end{array}$ & $\begin{array}{l}81 \pm 16 \\
(5)\end{array}$ & $\begin{array}{l}90 \pm 8 \\
(600)\end{array}$ & $\begin{array}{l}83 \pm 17 \\
(5)\end{array}$ & $\begin{array}{l}94 \pm 16 \\
(600)\end{array}$ & $\begin{array}{l}97 \pm 18 \\
(5)\end{array}$ & $\begin{array}{l}109 \pm 19 \\
(600)\end{array}$ & $87 \pm 9(5)$ & $\begin{array}{l}101 \pm 3 \\
(600)\end{array}$ & $\begin{array}{l}89 \pm 11 \\
(5)\end{array}$ & $\begin{array}{l}106 \pm 13 \\
(600)\end{array}$ \\
\hline 15 & $14(R S)-14-\mathrm{F}_{4 \mathrm{t}}-\mathrm{NeuroP}$ & $\begin{array}{l}71 \pm 30 \\
(5)\end{array}$ & $\begin{array}{l}94 \pm 15 \\
(600)\end{array}$ & $\begin{array}{l}110 \pm 51 \\
(5)\end{array}$ & $\begin{array}{l}89 \pm 7 \\
(600)\end{array}$ & $\begin{array}{l}70 \pm 30 \\
(5)\end{array}$ & $\begin{array}{l}86 \pm 4 \\
(600)\end{array}$ & $\begin{array}{l}50 \pm 27 \\
(5)\end{array}$ & $\begin{array}{l}80 \pm 10 \\
(600)\end{array}$ & $\begin{array}{l}106 \pm 41 \\
(5)\end{array}$ & $\begin{array}{l}94 \pm 4 \\
(600)\end{array}$ & $\begin{array}{l}89 \pm 36 \\
(5)\end{array}$ & $\begin{array}{l}90 \pm 9 \\
(600)\end{array}$ \\
\hline 16 & $4(R S)-\mathrm{ST}-\Delta^{5}-8$-NeuroF & $<\operatorname{LOD}(5)$ & $\begin{array}{l}105 \pm 16 \\
(600)\end{array}$ & $<\operatorname{LOD}(5)$ & $\begin{array}{l}131 \pm 30 \\
(600)\end{array}$ & $<\operatorname{LOD}(5)$ & $\begin{array}{l}70 \pm 30 \\
(600)\end{array}$ & $<\operatorname{LOD}(5)$ & $\begin{array}{l}80 \pm 20 \\
(600)\end{array}$ & $<\operatorname{LOQ}(5)$ & $\begin{array}{l}70 \pm 20 \\
(600)\end{array}$ & $<\operatorname{LOQ}(5)$ & $\begin{array}{l}110 \pm 40 \\
(600)\end{array}$ \\
\hline 17 & $\begin{array}{l}\text { 17- } \mathrm{F}_{2 \mathrm{t}} \text {-dihomo-IsoP }+17-\text { epi- } \\
17-\mathrm{F}_{2 \mathrm{t}} \text {-dihomo-IsoP }\end{array}$ & $\begin{array}{l}64 \pm 9 \\
(10)\end{array}$ & $\begin{array}{l}73 \pm 15 \\
(1200)\end{array}$ & $\begin{array}{l}61 \pm 8 \\
(10)\end{array}$ & $\begin{array}{l}72 \pm 2 \\
(1200)\end{array}$ & $\begin{array}{l}114 \pm 14 \\
(10)\end{array}$ & $\begin{array}{l}90 \pm 18 \\
(1200)\end{array}$ & $\begin{array}{l}123 \pm 14 \\
(10)\end{array}$ & $\begin{array}{l}100 \pm 16 \\
(1200)\end{array}$ & $\begin{array}{l}78 \pm 8 \\
(10)\end{array}$ & $\begin{array}{l}85 \pm 8 \\
(1200)\end{array}$ & $\begin{array}{l}67 \pm 20 \\
(10)\end{array}$ & $\begin{array}{l}85 \pm 9 \\
(1200)\end{array}$ \\
\hline 19 & ent-7(RS)- $\mathrm{F}_{2 \mathrm{t}}$-dihomo-IsoP & $\begin{array}{l}70 \pm 11 \\
(5)\end{array}$ & $\begin{array}{l}81 \pm 14 \\
(600)\end{array}$ & $\begin{array}{l}64 \pm 12 \\
(5)\end{array}$ & $\begin{array}{l}76 \pm 9 \\
(600)\end{array}$ & $\begin{array}{l}89 \pm 18 \\
(5)\end{array}$ & $\begin{array}{l}82 \pm 14 \\
(600)\end{array}$ & $\begin{array}{l}92 \pm 13 \\
(5)\end{array}$ & $\begin{array}{l}92 \pm 15 \\
(600)\end{array}$ & $65 \pm 6(5)$ & $\begin{array}{l}88 \pm 8 \\
(600)\end{array}$ & $\begin{array}{l}59 \pm 11 \\
(5)\end{array}$ & $\begin{array}{l}85 \pm 9 \\
(600)\end{array}$ \\
\hline 20 & $\begin{array}{l}\text { 17(RS)-10-epi-SC- } \Delta^{15}-11 \text { - } \\
\text { dihomo-IsoF }\end{array}$ & $\begin{array}{l}78 \pm 19 \\
(5)\end{array}$ & $\begin{array}{l}90 \pm 15 \\
(600)\end{array}$ & $\begin{array}{l}73 \pm 11 \\
(5)\end{array}$ & $\begin{array}{l}86 \pm 7 \\
(600)\end{array}$ & $\begin{array}{l}110 \pm 30 \\
(5)\end{array}$ & $\begin{array}{l}94 \pm 17 \\
(600)\end{array}$ & $\begin{array}{l}116 \pm 20 \\
(5)\end{array}$ & $\begin{array}{l}107 \pm 18 \\
(600)\end{array}$ & $\begin{array}{l}83 \pm 32 \\
(5)\end{array}$ & $\begin{array}{l}108 \pm 9 \\
(600)\end{array}$ & $\begin{array}{l}78 \pm 30 \\
(5)\end{array}$ & $\begin{array}{l}106 \pm 11 \\
(600)\end{array}$ \\
\hline 21 & $7(R S)$-ST- $\Delta^{8}$-11-dihomo-IsoF & $\begin{array}{l}87 \pm 17 \\
(5)\end{array}$ & $\begin{array}{l}100 \pm 17 \\
(600)\end{array}$ & $<\operatorname{LOD}(5)$ & $\begin{array}{l}95 \pm 6 \\
(600)\end{array}$ & $<\operatorname{LOD}(5)$ & $\begin{array}{l}116 \pm 20 \\
(600)\end{array}$ & $<\operatorname{LOD}(5)$ & $\begin{array}{l}131 \pm 30 \\
(600)\end{array}$ & $<\operatorname{LOQ}(5)$ & $\begin{array}{l}65 \pm 20 \\
(600)\end{array}$ & $<\operatorname{LOQ}(5)$ & $\begin{array}{l}84 \pm 30 \\
(600)\end{array}$ \\
\hline 3 & 15-keto-15- $\mathrm{F}_{2 \mathrm{t}}$-IsoP & $<\operatorname{LOD}(5)$ & $\begin{array}{l}<\text { LOD } \\
(600)\end{array}$ & $<\operatorname{LOD}(5)$ & $\begin{array}{l}<\text { LOD } \\
(600)\end{array}$ & $<\operatorname{LOD}(5)$ & $\begin{array}{l}85 \pm 13 \\
(600)\end{array}$ & $<\operatorname{LOD}(5)$ & $\begin{array}{l}101 \pm 20 \\
(600)\end{array}$ & $<\operatorname{LOQ}(5)$ & $\begin{array}{l}<\mathrm{LOQ} \\
(600)\end{array}$ & $<\operatorname{LOQ}(5)$ & $\begin{array}{l}<\mathrm{LOQ} \\
(600)\end{array}$ \\
\hline 18 & 1a,1b-dihomo-PGF $2 \alpha$ & $\begin{array}{l}52 \pm 11 \\
(5)\end{array}$ & $\begin{array}{l}62 \pm 11 \\
(600)\end{array}$ & $<\operatorname{LOD}(5)$ & $\begin{array}{l}60 \pm 5 \\
(600)\end{array}$ & $\begin{array}{l}150 \pm 40 \\
(5)\end{array}$ & $\begin{array}{l}107 \pm 20 \\
(600)\end{array}$ & $\begin{array}{l}180 \pm 40 \\
(5)\end{array}$ & $\begin{array}{l}120 \pm 20 \\
(600)\end{array}$ & $33 \pm 6(5)$ & $\begin{array}{l}72 \pm 5 \\
(600)\end{array}$ & $\begin{array}{l}38 \pm 13 \\
(5)\end{array}$ & $\begin{array}{l}77 \pm 11 \\
(600)\end{array}$ \\
\hline 5 & $15-\mathrm{F}_{2 \mathrm{t}}$-IsoP & $\begin{array}{l}82 \pm 16 \\
(5)\end{array}$ & $\begin{array}{l}97 \pm 11 \\
(600)\end{array}$ & $79 \pm 5(5)$ & $\begin{array}{l}87 \pm 16 \\
(600)\end{array}$ & $\begin{array}{l}95 \pm 20 \\
(5)\end{array}$ & $\begin{array}{l}86 \pm 10 \\
(600)\end{array}$ & $\begin{array}{l}101 \pm 15 \\
(5)\end{array}$ & $\begin{array}{l}101 \pm 18 \\
(600)\end{array}$ & $\begin{array}{l}87 \pm 15 \\
(5)\end{array}$ & $\begin{array}{l}99 \pm 1 \\
(600)\end{array}$ & $\begin{array}{l}86 \pm 18 \\
(5)\end{array}$ & $\begin{array}{l}99 \pm 9 \\
(600)\end{array}$ \\
\hline 8 & $15-\mathrm{E}_{2 \mathrm{t}}$-IsoP & $<\operatorname{LOD}(5)$ & $\begin{array}{l}<\text { LOD } \\
(600)\end{array}$ & $<\operatorname{LOD}(5)$ & $\begin{array}{l}<\text { LOD } \\
(600)\end{array}$ & $<\operatorname{LOD}(5)$ & $\begin{array}{l}83 \pm 15 \\
(600)\end{array}$ & $<\operatorname{LOD}(5)$ & $\begin{array}{l}130 \pm 9 \\
(600)\end{array}$ & $<\operatorname{LOQ}(5)$ & $\begin{array}{l}<\text { LOQ } \\
(600)\end{array}$ & $<\operatorname{LOQ}(5)$ & $\begin{array}{l}<\text { LOQ } \\
(600)\end{array}$ \\
\hline 6 & $11 \beta-\mathrm{PGF}_{2 \alpha}$ & $\begin{array}{l}100 \pm 20 \\
(5)\end{array}$ & $\begin{array}{l}96 \pm 14 \\
(600)\end{array}$ & $\begin{array}{l}80 \pm 30 \\
(5)\end{array}$ & $\begin{array}{l}88 \pm 13 \\
(600)\end{array}$ & $\begin{array}{l}100 \pm 20 \\
(5)\end{array}$ & $\begin{array}{l}89 \pm 14 \\
(600)\end{array}$ & $\begin{array}{l}120 \pm 30 \\
(5)\end{array}$ & $\begin{array}{l}104 \pm 19 \\
(600)\end{array}$ & $89 \pm 6(5)$ & $\begin{array}{l}99 \pm 1 \\
(600)\end{array}$ & $\begin{array}{l}84 \pm 13 \\
(5)\end{array}$ & $\begin{array}{l}100 \pm 10 \\
(600)\end{array}$ \\
\hline 4 & 15-epi-15- $\mathrm{F}_{2 \mathrm{t}}$-IsoP & $\begin{array}{l}101 \pm 15 \\
(5)\end{array}$ & $\begin{array}{l}106 \pm 17 \\
(600)\end{array}$ & $\begin{array}{l}90 \pm 20 \\
(5)\end{array}$ & $\begin{array}{l}95 \pm 15 \\
(600)\end{array}$ & $\begin{array}{l}87 \pm 10 \\
(5)\end{array}$ & $\begin{array}{l}125 \pm 2 \\
(600)\end{array}$ & $\begin{array}{l}75 \pm 15 \\
(5)\end{array}$ & $\begin{array}{l}100 \pm 20 \\
(600)\end{array}$ & $\begin{array}{l}111 \pm 12 \\
(5)\end{array}$ & $\begin{array}{l}96 \pm 5 \\
(600)\end{array}$ & $\begin{array}{l}102 \pm 13 \\
(5)\end{array}$ & $\begin{array}{l}101 \pm 13 \\
(600)\end{array}$ \\
\hline 10 & 6-keto-PGF $1 \alpha$ & $\begin{array}{l}107 \pm 16 \\
(5)\end{array}$ & $\begin{array}{l}87 \pm 13 \\
(600)\end{array}$ & $\begin{array}{l}95 \pm 18 \\
(5)\end{array}$ & $\begin{array}{l}87 \pm 1 \\
(600)\end{array}$ & $\begin{array}{l}97 \pm 17 \\
(5)\end{array}$ & $\begin{array}{l}100 \pm 2 \\
(600)\end{array}$ & $\begin{array}{l}85 \pm 17 \\
(5)\end{array}$ & $\begin{array}{l}92 \pm 10 \\
(600)\end{array}$ & $\begin{array}{l}79 \pm 12 \\
(5)\end{array}$ & $\begin{array}{l}91 \pm 2 \\
(600)\end{array}$ & $80 \pm 8(5)$ & $\begin{array}{l}94 \pm 10 \\
(600)\end{array}$ \\
\hline 7 & $\mathrm{PGF}_{2 \alpha}$ & $\begin{array}{l}115 \pm 11 \\
(5)\end{array}$ & $\begin{array}{l}94 \pm 15 \\
(600)\end{array}$ & $\begin{array}{l}106 \pm 12 \\
(5)\end{array}$ & $\begin{array}{l}86 \pm 14 \\
(600)\end{array}$ & $34 \pm 8(5)$ & $\begin{array}{l}82 \pm 10 \\
(600)\end{array}$ & $\begin{array}{l}32 \pm 10 \\
(5)\end{array}$ & $\begin{array}{l}100 \pm 20 \\
(600)\end{array}$ & $\begin{array}{l}120 \pm 16 \\
(5)\end{array}$ & $\begin{array}{l}103 \pm 6 \\
(600)\end{array}$ & $\begin{array}{l}100 \pm 18 \\
(5)\end{array}$ & $\begin{array}{l}102 \pm 10 \\
(600)\end{array}$ \\
\hline 11 & 15-keto-15-E 2 -IsoP & $<\operatorname{LOD}(5)$ & $\begin{array}{l}<\text { LOD } \\
(600)\end{array}$ & $<\operatorname{LOD}(5)$ & $\begin{array}{l}<\text { LOD } \\
(600)\end{array}$ & $\begin{array}{l}119 \pm 16 \\
(5)\end{array}$ & $\begin{array}{l}129 \pm 1 \\
(600)\end{array}$ & $\begin{array}{l}110 \pm 20 \\
(5)\end{array}$ & $\begin{array}{l}100 \pm 30 \\
(600)\end{array}$ & $<$ LOQ (5) & $\begin{array}{l}<\mathrm{LOQ} \\
(600)\end{array}$ & $<$ LOQ (5) & $\begin{array}{l}<\mathrm{LOQ} \\
(600)\end{array}$ \\
\hline 9 & $\mathrm{PGE}_{2}$ & $<\operatorname{LOD}(5)$ & $\begin{array}{l}<\text { LOD } \\
(600)\end{array}$ & $<\operatorname{LOD}(5)$ & $\begin{array}{l}<\text { LOD } \\
(600)\end{array}$ & $\begin{array}{l}90 \pm 20 \\
(5)\end{array}$ & $\begin{array}{l}78 \pm 11 \\
(600)\end{array}$ & $\begin{array}{l}100 \pm 20 \\
(5)\end{array}$ & $\begin{array}{l}93 \pm 17 \\
(600)\end{array}$ & $<\operatorname{LOQ}(5)$ & $\begin{array}{l}<\mathrm{LOQ} \\
(600)\end{array}$ & $<\operatorname{LOQ}(5)$ & $\begin{array}{l}<\mathrm{LOQ} \\
(600)\end{array}$ \\
\hline
\end{tabular}

Note: Values within brackets indicate the added concentration of each metabolite added to the plasma sample; ${ }^{a}$ indicates the peak number according to Fig. 1. 
as IS generally covering two to three orders of magnitude were obtained with coefficients of determination $\left(R^{2}\right)>0.97$ and homoscedastic residuals as assessed by visual inspection. LOD and LOQ expressed as nmol $\mathrm{L}^{-1}$ of plasma were in the $0.11-53$ and $0.4-178$ range, respectively. No carry-over was observed with peak areas of the blank injection remaining below $5 \%$ of the signal of the standard at the LOD.

Table 3 shows back-calculated recovery values in standard solutions for assessment of accuracy and precision. Adequate accuracies were obtained in standard solutions with the exception of $17(R S)-10$-epi-SC- $\Delta^{15}$-11-dihomo-IsoF and $1 \mathrm{a}, 1 \mathrm{~b}-$ dihomo-PGF $2 \alpha$. Precision levels remained $<20 \%$ at the LOQ and $<15 \%$ for higher concentrations, with the exception of the intra-day precision obtained for $15-\mathrm{E}_{2 \mathrm{t}}$-IsoP. In Table 4 the method's performance was further assessed by the analysis of spiked plasma samples and calculated recovery values taking into account the concentrations found in the non-spiked sample. The extraction yields were used for jointly assessing the effect of the $\mathrm{KOH}$ digestion procedure and the solid phase extraction sample clean-up. Good inter- and intraday extraction yields ranging between 82 and $115 \%$ and 79 and $131 \%$ were found for lipid peroxidation products derived from AA and DHA with the exception of four metabolites derived from AA (i.e.

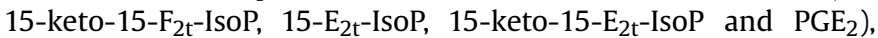
which were not detected. It is suspected that during sample hydrolysis these analytes suffer dehydration within the $\beta$-hydroxyketo system in the cyclopentane ring (i.e. cyclopentenone PGs) [7] while the $\delta$-hydroxy- $\alpha, \beta$-unsaturated-keto system of 15 -keto-15$\mathrm{F}_{2 \mathrm{t}}$-IsoP is degrading into a reactive conjugated keto-diene system. AdA derived lipid peroxidation products showed lower extraction yields ranging between 52 and $100 \%$ and 60 and $95 \%$ for inter- and intra-day accuracy, indicating that those compounds are either partially degraded during the digestion step or not completely recovered during the SPE. As observed from Table 4, for a total of seven compounds a notable matrix effect was observed whereas for the remaining compounds intra- and inter-day recoveries ranged between $78-129 \%$ and $75-123 \%$, respectively. No pattern between different lipid peroxidation classes could be detected with respect to the matrix effect. Moreover, the overall accuracy and precision of the developed method was assessed for all metabolites which were not degraded during the hydrolysis procedure by means of relative recovery values employing deuterated ISs. For AA and DHA derived lipid peroxidation products obtained intra- and inter-day accuracy levels ranged between 79 and $120 \%$ and 80 and $113 \%$, respectively, with the exception of $4(\mathrm{RS})-\mathrm{ST}-\Delta^{5}-8$-NeuroF for which only a semiquantitative determination was achieved despite the use of an IS. Due to the low extraction yields observed for dihomo-IsoPs and dihomo-IsoFs a semiquantitative determination was proposed to enable the comparison of samples analyzed and extracted under the same conditions. Complementary approaches such as including isotopically labelled analogues of dihomo-IsoPs and dihomo-IsoFs as surrogates to improve the accuracy of the method are being evaluated. In summary, data shown in Table 4 prove that the developed method is highly reproducible for the analysis of the majority of compounds while it gives insights in the analytical challenges for several other compounds which might be affected during sample processing and measurement.

\subsection{Quantitative analysis of lipid peroxidation biomarkers in newborn plasma samples}

Lipid peroxidation biomarkers were determined in 150 plasma samples from 20 term newborns suffering from HIE secondary to birth asphyxia (see Table 1 ) at 10 sampling time points covering from 3 h to 6 days after birth. Table 5 shows the main descriptors of the distribution of concentrations of the lipid peroxidation products found in the studied samples excluding the four metabolites which were not stable during the sample $\mathrm{KOH}$ hydrolysis process (i.e. 15-keto-15- $\mathrm{F}_{2 \mathrm{t}}-\mathrm{IsoP}, 15-\mathrm{E}_{2 \mathrm{t}}$-IsoP, 15-keto-15- $\mathrm{E}_{2 \mathrm{t}}$-IsoP and $\mathrm{PGE}_{2}$ ). From the 17 remaining parameters, 11 (corresponding to 16 individual isoprostanoids) were detected in the studied samples. In addition to the determination of individual lipid peroxidation biomarkers, total relative IsoP, IsoF, NeuroP and NeuroF contents were measured following a procedure as described elsewhere [14]. Three out of the 11 compounds have been detected in a preliminary biomarker study involving a

Table 5

Main descriptors of the distribution of concentrations $(\mathrm{nM})$ of the lipid peroxidation products in plasma samples with concentrations > LOQ from newborns with HIE.

\begin{tabular}{|c|c|c|c|c|c|c|}
\hline$\#^{\mathrm{a}}$ & Analyte & Range & Median & IQR (25-75) & Mean $\pm s$ & $>$ LOQ $(\%)$ \\
\hline 1 & 5-F ${ }_{2 t}-$ IsoP + 5-epi-5-F ${ }_{2 t}$-IsoP & $0.5-8.6$ & 3.2 & 1.9 & $3.5 \pm 1.3$ & 44 \\
\hline 2 & $\begin{array}{l}\text { 15-epi-2,3-dinor-15-F } \mathrm{F}_{2 \mathrm{t}} \text {-IsoP }+ \\
\text { 2,3-dinor-11 } \beta-\text { PGF }_{2 \alpha}+ \\
\text { 2,3-dinor-15-F } \text { F }_{2 \alpha} \text {-IsoP }\end{array}$ & - & - & - & - & 0 \\
\hline 12 & $\begin{array}{l}\text { 4-F } \text { Ft }_{4}-\text { NeuroP }+ \\
\text { 4-epi-4-F } \\
4 \mathrm{t}-\text { NeuroP }\end{array}$ & $1.1-1.6$ & 1.3 & 0.2 & $1.3 \pm 0.2$ & 7 \\
\hline 13 & 10-epi-10-F $\mathrm{F}_{4 \mathrm{t}}$-NeuroP & $0.4-0.8$ & 0.4 & 0.1 & $0.5 \pm 0.1$ & 9 \\
\hline 14 & $10-F_{4 t}-$ NeuroP & $0.4-0.8$ & 0.5 & 0.09 & $0.53 \pm 0.12$ & 13 \\
\hline 15 & 14(RS)-14-F $4 \mathrm{t}-$ NeuroP & - & - & - & - & 0 \\
\hline 16 & $4(R S)$-ST- $\Delta^{5}-8$-NeuroF & - & - & - & - & 0 \\
\hline 17 & 17-F $\mathrm{F}_{2 \mathrm{t}}$-dihomo-IsoP + 17-epi-17-F $\mathrm{F}_{2 \mathrm{t}}$-dihomo-IsoP & $0.5-1.1$ & 0.8 & 0.1 & $0.8 \pm 0.2$ & 5 \\
\hline 19 & ent-7(RS)-F $F_{2 t}$-dihomo-IsoP & $0.3-1.0$ & 0.5 & 0.1 & $0.5 \pm 0.2$ & 4 \\
\hline 20 & 17(RS)-10-epi-SC- $\Delta^{15}$-11-dihomo-IsoF & $0.4-3.2$ & 0.6 & 0.4 & $0.8 \pm 0.6$ & 61 \\
\hline 21 & $7(R S)$-ST- $\Delta^{8}$-11-dihomo-IsoF & $89.9-900.7$ & 174.5 & 151.7 & $240 \pm 170$ & 74 \\
\hline 18 & 1a,1b-dihomo-PGF $2 \alpha$ & $0.8-2.9$ & 1.1 & 0.45 & $1.2 \pm 0.4$ & 37 \\
\hline 5 & 15-F Ft -IsoP & - & - & - & - & 0 \\
\hline 6 & $11 \beta-P_{G F} \alpha$ & - & - & - & - & 0 \\
\hline 4 & 15-epi-15-F ${ }_{2 t}$-IsoP & - & - & - & - & 0 \\
\hline 10 & 6-keto-PGF $1 \alpha$ & $0.4-0.8$ & 0.5 & 0.1 & $0.6 \pm 0.1$ & 3 \\
\hline 7 & $\mathbf{P G F}_{2 \alpha}$ & $0.8-10.8$ & 2.5 & 1.2 & $2.6 \pm 1.1$ & 98 \\
\hline- & Isoprostanes $^{\mathrm{b}}$ & - & - & - & - & 0 \\
\hline - & Isofurans $^{\mathrm{b}}$ & $19.8-184.5$ & 52.1 & 50 & $70 \pm 40$ & 76 \\
\hline- & Neuroprostanes $^{\mathrm{b}}$ & $20-114$ & 50.3 & 23 & $50 \pm 20$ & 29 \\
\hline- & Neurofurans ${ }^{\mathrm{b}}$ & $8-27$ & 14.5 & 7 & $15 \pm 4$ & 69 \\
\hline
\end{tabular}

Note: ${ }^{\mathrm{a}}$ indicates the peak number according to Fig. 1 ; ${ }^{\mathrm{b}}$ Values in area/area of internal standard $\times 1000$. 

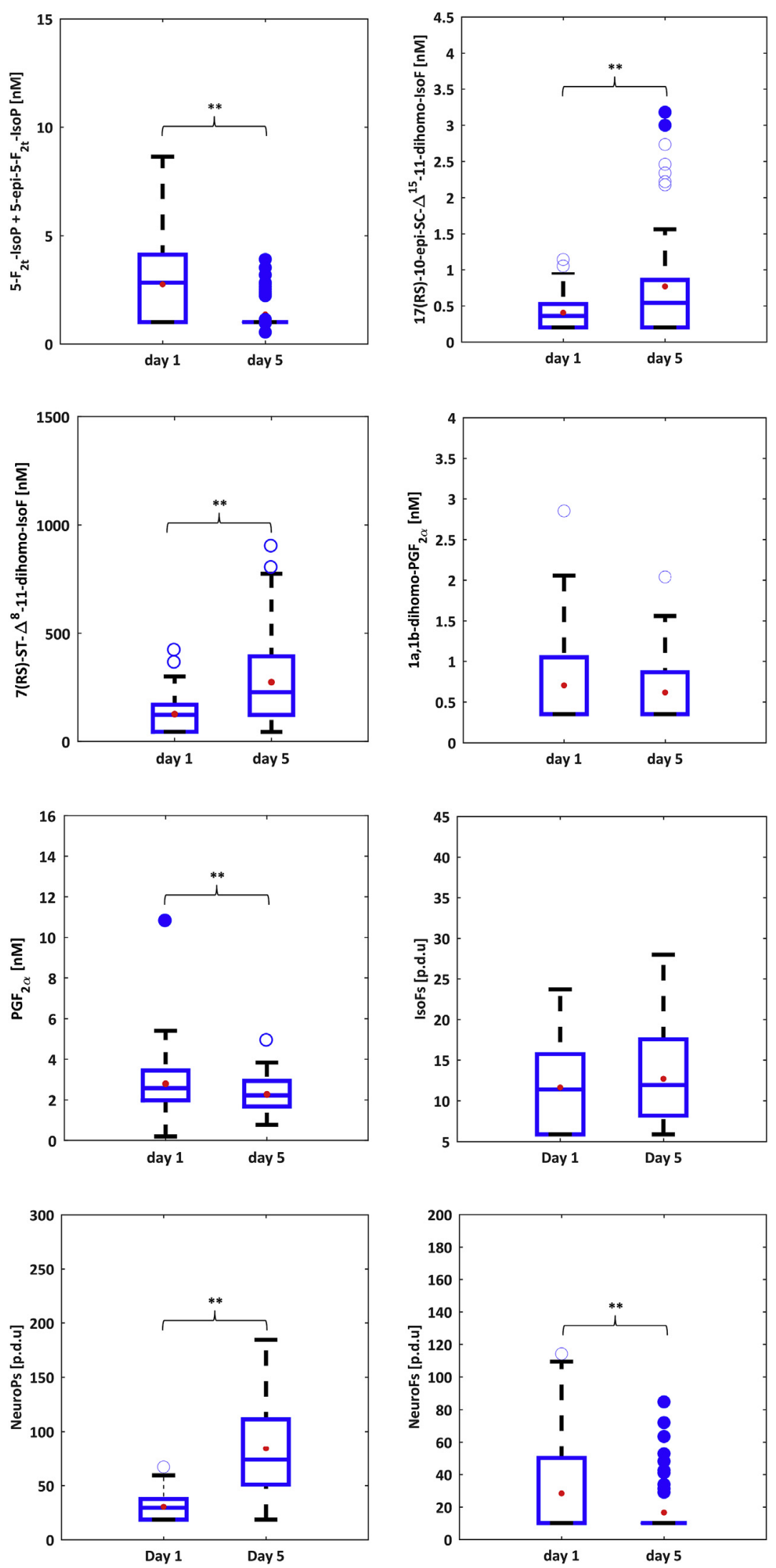

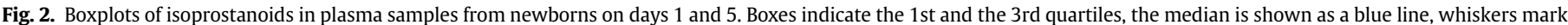

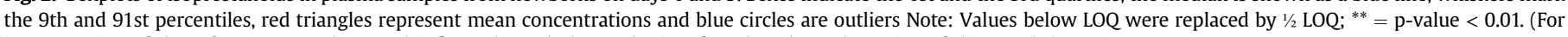
interpretation of the references to colour in this figure legend, the reader is referred to the web version of this article.) 
similar cohort of newborns $(\mathrm{N}=20)$ [15]. In newborns with HIE undergoing $\mathrm{TH}$ concentrations determined were of the same order of magnitude as in this cohort with medians (IQRs) of 3 (12), 5(7) and 0 (3.4) for 5-F2t-IsoP, PGF $_{2 \alpha}$ and $1 \mathrm{a}, 1 \mathrm{~b}-$ dihomo-PGF $2 \alpha$, respectively.

Fig. 2 shows boxplots of the results of isoprostanoids which were detected in more than $25 \%$ of samples. The results are stratified by two collection time windows, the first one comprising the first $30 \mathrm{~h}$ after birth during hypothermia and the second including samples collected on day 5-6 during normothermia. Interestingly, not all metabolites showed the same behavior with time. In a previous study the levels of total IsoPs, IsoFs, NeuroPs and NeuroFs were monitored in preterm infants throughout the whole neonatal period and nomograms of relative contents were established revealing the underlying changes of biomarker levels as a function of the infant's age [14]. This might be an important aspect to be taken into account during the experimental design of clinical studies as well as during the interpretation of the results. Here, a significant decrease with time was detected for some metabolites (i.e. 5- $\mathrm{F}_{2 \mathrm{t}}$-IsoP + 5-epi-5-F $2 \mathrm{t}-\mathrm{IsoP}, \mathrm{PGF}_{2 \alpha}$, total NeuroFs), whereas others increased (i.e. 17(RS)-10-epi-SC- $\Delta^{15}$-11-dihomo-IsoF, 7(RS)ST- $\Delta^{8}$-11-dihomo-IsoF, total NeuroPs) or remained unchanged (1a,1b-dihomo-PGF $2 \alpha$, total IsoFs). This application illustrates the strengths of a detection method which is able to detect and quantify specific isomers as compared to the determination of total parameters. Also, the specific detection of isomers enables an absolute quantification, which at the same time improves the method's sensitivity. This is also demonstrated in the present study by the detection of IsoPs: whereas for total IsoPs the concentrations remained below the LOQ some individual IsoPs could still be detected (i.e. 5- $\mathrm{F}_{2 \mathrm{t}}$-IsoP $+5-$-epi-5- $\mathrm{F}_{2 \mathrm{t}}$-IsoP). Conversely, for IsoFs no analytical standard solutions were available and the determination of total IsoFs enabled the detection of these metabolites in plasma samples. Likewise, in case of NeuroPs and NeuroFs, individual isomers could not be detected in the majority of samples, whereas for the total parameters levels above the LOQ were found, indicating that the individual isomers included in this method might not be those which were formed primarily. Hence, the simultaneous determination of both, individual isomers and total parameters is recommended for studying lipid peroxidation biomarkers in biofluids. Whereas the individual isomers give a more detailed information on the lipid peroxidation process providing insight into the underlying mechanisms of action, total parameters are a straightforward alternative when no pure analytical standard solutions are available. Moreover, even if the determination of individual isomers was not limited by the availability of standards, it would not be feasible to resolve and determine all possible isomers in one analytical run. Therefore, it would first have to be established which lipid peroxidation biomarkers are of interest for monitoring in each study in dependence of the species, biofluid and pathophysiological situation.

\section{Conclusions}

This work presents the first validated LC-MS/MS method for the simultaneous quantification of 28 lipid peroxidation biomarkers in addition to four total relative parameters in small volumes $(100 \mu \mathrm{L})$ of plasma samples. The access to a considerable panel of different isomers allowed an in-depth study of the effect of analytical and pre-analytical conditions on the determination of the metabolites revealing stability issues in 4 metabolites during hydrolysis. Future studies will focus on the modification of the hydrolysis conditions e.g. using enzymatic hydrolysis. Furthermore the use of isotopically labelled internal standards for each studied substance class as surrogates is recommended to improve the method's accuracy.
The validated method was applied to a total of 150 plasma samples from newborns, with small sample volumes of between 40 and $100 \mu \mathrm{L}$ available. The obtained results revealed changes in some of the detected biomarkers with time, whereas others remained constant. In the present study, samples were stored without the addition of antioxidants as recommended in the literature [17]. Future work focusing on a systematic evaluation of the effect of storage and the use of antioxidants will be necessary for implementing a reliable protocol for the determination of lipid peroxidation biomarkers in clinical studies. The advantages and pitfalls of the detection of total relative parameters in comparison to individual isomers have been critically discussed and the simultaneous use of both detection approaches is encouraged.

\section{Acknowledgements}

The project received funding from the Instituto Carlos III (FISPI14/ 0433), Spanish Ministry of Health, Social Services and Equality (EC11246), and Institute of Translational Medicine \& Therapeutics (ITMAT), National Institute for Health Research (NIHR) Biomedical Research Centre (BRC), Imperial College London (P60743). Furthermore, the authors acknowledge financial support from the Research Network on Maternal and Child Health and Development Retic Red SAMID RD12/0026/11 and FEDER funding from the European Union (Instituto Carlos III, Ministry of Economy and Competitiveness, Spain). JK acknowledges funding from the Conselleria de Educación, Investigación, Cultura y Deporte of the Generalitat Valenciana (GV 2016/ 062). JK and ASI are grateful for their personal Miguel Servet and PFIS grants (CP16/00034 and FI16/00380) provided by the Instituto Carlos III (Ministry of Economy and Competitiveness, Spain).

\section{Appendix A. Supplementary data}

Supplementary data related to this article can be found at https://doi.org/10.1016/j.aca.2017.09.026.

\section{References}

[1] I. Torres-Cuevas, M. Cernada, A. Nuñez, J. Escobar, J. Kuligowski, C. ChaferPericas, M. Vento, Oxygen supplementation to stabilize preterm infants in the fetal to neonatal transition: No satisfactory answer, Front. Pediatr. 4 (2016), https://doi.org/10.3389/fped.2016.00029.

[2] J. Belik, G.E. González-Luis, F. Perez-Vizcaino, E. Villamor, Isoprostanes in fetal and neonatal health and disease, Free Radic. Biol. Med. 48 (2010) 177-188, https://doi.org/10.1016/j.freeradbiomed.2009.10.043.

[3] N. Merchant, D. Azzopardi, Early predictors of outcome in infants treated with hypothermia for hypoxic-ischaemic encephalopathy, Dev. Med. Child. Neurol. 57 (Suppl 3) (2015) 8-16, https://doi.org/10.1111/dmcn.12726.

[4] M. Vento, H. Hummler, J. Dawson, J. Escobar, J. Kuligowski, Use of oxygen in the resuscitation of neonates, in: P.A. Dennery, G. Buonocore, O.D. Saugstad (Eds.), Perinat. Prenat. Disord, Humana Press, New York, 2014, pp. 213-244.

[5] R. Solberg, M. Longini, F. Proietti, P. Vezzosi, O.D. Saugstad, G. Buonocore, Resuscitation with supplementary oxygen induces oxidative injury in the cerebral cortex, Free Radic. Biol. Med. 53 (2012) 1061-1067, https://doi.org/ 10.1016/j.freeradbiomed.2012.07.022.

[6] J.D. Morrow, K.E. Hill, R.F. Burk, T.M. Nammour, K.F. Badr, L.J. Roberts 2nd, A series of prostaglandin F2-like compounds are produced in vivo in humans by a non-cyclooxygenase, free radical-catalyzed mechanism, Proc. Natl. Acad. Sci. U. S. A. 87 (1990) 9383-9387.

[7] G.L. Milne, Q. Dai, L.J. Roberts, The isoprostanes-25 years later, Biochim. $\begin{array}{llll}\text { Biophys. Acta } 1851 & \text { (2015) 433-445, https://doi.org/10.1016/ }\end{array}$ j.bbalip.2014.10.007.

[8] G.L. Milne, H. Yin, K.D. Hardy, S.S. Davies, L.J. Roberts 2nd, Isoprostane generation and function, Chem. Rev. 111 (2011) 5973-5996, https://doi.org 10.1021/cr200160h.

[9] U. Jahn, J.-M. Galano, T. Durand, Beyond prostaglandins-chemistry and biology of cyclic oxygenated metabolites formed by free-radical pathways from polyunsaturated fatty acids, Angew. Chem. Int. Ed. Engl. 47 (2008) 5894-5955, https://doi.org/10.1002/anie.200705122.

[10] W.-L. Song, J.A. Lawson, D. Reilly, J. Rokach, C.-T. Chang, B. Giasson, G.A. FitzGerald, Neurofurans, novel indices of oxidant stress derived from docosahexaenoic acid, J. Biol. Chem. 283 (2008) 6-16, https://doi.org/ 10.1074/jbc.M706124200. 
[11] H.-C. Yen, H.-J. Wei, C.-L. Lin, Unresolved issues in the analysis of F2isoprostanes, F4-neuroprostanes, isofurans, neurofurans, and F2-dihomoisoprostanes in body fluids and tissue using gas chromatography/negative-ion chemical-ionization mass spectrometry, Free Radic. Res. 49 (2015) 861-880, https://doi.org/10.3109/10715762.2015.1014812.

[12] S. Perrone, M.L. Tataranno, G. Stazzoni, G. Buonocore, Biomarkers of oxidative stress in fetal and neonatal diseases, J. Matern. Fetal Neonatal Med. 25 (2012) 2575-2578, https://doi.org/10.3109/14767058.2012.718004.

[13] G. Tonni, S. Leoncini, C. Signorini, L. Ciccoli, C.D. Felice, Pathology of perinata brain damage: background and oxidative stress markers, Arch. Gynecol. Obstet. 290 (2014) 13-20, https://doi.org/10.1007/s00404-014-3208-6.

[14] J. Kuligowski, M. Aguar, D. Rook, I. Lliso, I. Torres-Cuevas, J. Escobar, G. Quintás, M. Brugada, A. Sánchez-Illana, J.B. van Goudoever, M. Vento, Urinary lipid peroxidation byproducts: are they relevant for predicting neonatal morbidity in preterm infants? Antioxid. Redox Signal 23 (2015) 178-184 https://doi.org/10.1089/ars.2015.6262.

[15] C. Chafer-Pericas, M. Cernada, L. Rahkonen, V. Stefanovic, S. Andersson, M. Vento, Preliminary case control study to establish the correlation between novel peroxidation biomarkers in cord serum and the severity of hypoxic ischemic encephalopathy, Free Radic. Biol. Med. 97 (2016) 244-249, https:/| doi.org/10.1016/j.freeradbiomed.2016.06.006.

[16] Y.Y. Lee, J.-M. Galano, C. Oger, C. Vigor, R. Guillaume, J. Roy, J.-Y. Le Guennec T. Durand, J.C.-Y. Lee, Assessment of isoprostanes in human plasma: technica considerations and the use of mass spectrometry, Lipids 51 (2016) 1217-1229, https://doi.org/10.1007/s11745-016-4198-x.

[17] G.L. Milne, B. Gao, E.S. Terry, W.E. Zackert, S.C. Sanchez, Measurement of F2 isoprostanes and isofurans using gas chromatography-mass spectrometry, Free Radic. Biol. Med. 59 (2013) 36-44, https://doi.org/10.1016 j.freeradbiomed.2012.09.030.

[18] C. Cháfer-Pericás, L. Rahkonen, A. Sánchez-Illana, J. Kuligowski, I. TorresCuevas, M. Cernada, E. Cubells, A. Nuñez-Ramiro, S. Andersson, M. Vento, J. Escobar, Ultra high performance liquid chromatography coupled to tandem mass spectrometry determination of lipid peroxidation biomarkers in newborn serum samples, Anal. Chim. Acta 886 (2015) 214-220, https:| doi.org/10.1016/j.aca.2015.06.028

[19] C. Cháfer-Pericás, I. Torres-Cuevas, A. Sanchez-Illana, J. Escobar, J. Kuligowski, R. Solberg, H.T. Garberg, M.U. Huun, O.D. Saugstad, M. Vento, Development of a reliable analytical method to determine lipid peroxidation biomarkers in newborn plasma samples, Talanta 153 (2016) 152-157, https://doi.org/ 10.1016/j.talanta.2016.03.010.

[20] A. Dupuy, P. Le Faouder, C. Vigor, C. Oger, J-M. Galano, C. Dray, J.C.-Y. Lee P. Valet, C. Gladine, T. Durand, J. Bertrand-Michel, Simultaneous quantitative profiling of 20 isoprostanoids from omega-3 and omega- 6 polyunsaturated fatty acids by LC-MS/MS in various biological samples, Anal. Chim. Acta 921 (2016) 46-58, https://doi.org/10.1016/j.aca.2016.03.024.

[21] I. De Las Heras-Gómez, S. Medina, T. Casas-Pina, L. Marín-Soler, A. Tomás, P. Martínez-Hernández, C. Oger, J.-M. Galano, T. Durand, L. Jimeno, S. Llorente, E. Lozoya, F. Ferreres, A. Gil-Izquierdo, Potential applications of lipid peroxidation products - F4-neuroprostanes, F3-neuroprostanesn-6 DPA, F2dihomo-isoprostanes and F2-isoprostanes - in the evaluation of the allograft function in renal transplantation, Free Radic. Biol. Med. 104 (2017) 178-184, https://doi.org/10.1016/j.freeradbiomed.2017.01.019.

[22] T. Durand, A. Guy, O. Henry, J.-P. Vidal, J.-C. Rossi, C. Rivalta, A. Valagussa, C. Chiabrando, Total syntheses of four metabolites of 15-F2t-isoprostane, Eur. J. Org. Chem. 2001 (2001) 809-819, https://doi.org/10.1002/10990690(200102)2001:4<809::AID-EJOC809>3.0.CO;2-6.

[23] D. T, C. Jl, G. A. R. Jc, Syntheses and preliminary pharmacological evaluation of the two epimers of the 5-F2t-isoprostane, Bioorg. Med. Chem. Lett. 11 (2001) 2495-2498, https://doi.org/10.1016/S0960-894X(01)00473-5.

[24] Total synthesis of 4(RS)-F4t-isoprostane methyl ester| Thierry Durand Academia.edu, (n.d.). http://www.academia.edu/13386671/Total_synthesis of_4_RS_-F4t-isoprostane_methyl_ester (accessed May 26, 2017).

[25] C. Oger, V. Bultel-Poncé, A. Guy, L. Balas, J.-C. Rossi, T. Durand, J.-M. Galano, The handy use of Brown's P2-Ni catalyst for a skipped diyne deuteration: application to the synthesis of a [D4]-labeled F4t-neuroprostane, Chem. Weinh. Bergstr. Ger. 16 (2010) 13976-13980, https://doi.org/10.1002/ chem.201002304.

[26] C. Oger, V. Bultel-Poncé, A. Guy, T. Durand, J.-M. Galano, Total synthesis of isoprostanes derived from adrenic acid and EPA, Eur. J. Org. Chem. 2012 (2012) 2621-2634, https://doi.org/10.1002/ejoc.201200070.

[27] A. Guy, C. Oger, J. Heppekausen, C. Signorini, C. De Felice, A. Fürstner, T. Durand, J.-M. Galano, Oxygenated metabolites of n-3 polyunsaturated fatty acids as potential oxidative stress biomarkers: total synthesis of 8-F3t-IsoP, 10-F4t-NeuroP and [D4]-10-F4t-NeuroP, Chem. Weinh. Bergstr. Ger. 20 (2014) 6374-6380, https://doi.org/10.1002/chem.201400380.

[28] A. de La Torre, Y.Y. Lee, C. Oger, P.T. Sangild, T. Durand, J.C.-Y. Lee, J.-M. Galano, Synthesis, Discovery, and quantitation of dihomo-isofurans: biomarkers for in vivo adrenic acid peroxidation, Angew. Chem. Int. Ed. 53 (2014) 6249-6252, https://doi.org/10.1002/anie.201402440.

[29] A. de la Torre, Y.Y. Lee, A. Mazzoni, A. Guy, V. Bultel-Poncé, T. Durand, C. Oger, J.C.-Y. Lee, J.-M. Galano, Total syntheses and in vivo quantitation of novel neurofuran and dihomo-isofuran derived from docosahexaenoic acid and adrenic acid, Chem. - Eur. J. 21 (2015) 2442-2446, https://doi.org/10.1002/ chem.201405497.

[30] J. Kuligowski, J. Escobar, G. Quintás, I. Lliso, I. Torres-Cuevas, A. Nuñez, E. Cubells, D. Rook, J.B. van Goudoever, M. Vento, Analysis of lipid peroxidation biomarkers in extremely low gestational age neonate urines by UPLC-MS/ MS, Anal. Bioanal. Chem. 406 (2014) 4345-4356, https://doi.org/10.1007/ s00216-014-7824-6.

[31] N.E. Bastani, T.E. Gundersen, R. Blomhoff, Determination of 8-epi PGF2 $\alpha$ concentrations as a biomarker of oxidative stress using triple-stage liquid chromatography/tandem mass spectrometry, Rapid Commun. Mass Spectrom. 23 (2009) 2885-2890, https://doi.org/10.1002/rcm.4197.

[32] Food and Drug Administration (FDA), Guidance for Industry: Bioanalytical Method Validation, 2001. 